\title{
Döngele Kaplıcası (Kahramanmaraş)'nın Termal Turizm Potansiyeli ve Sosyo-Ekonomik Katkıları ${ }^{1}$
}

\section{Nadire KARADEMIR}

Dr. Öğr. Üyesi, Kahramanmaraş Sütçü İmam Üniversitesi, Fen Edebiyat

Fakültesi, Coğrafya Bölümü, n.karademir45@gmail.com

Orcid ID: https://orcid.org/0000-0002-5850-0580

\section{Ersin Kaya SANDAL}

Prof. Dr., Kahramanmaraş Sütçü İmam Üniversitesi, Fen Edebiyat Fakültesi, Coğrafya Bölümü, esandal@ksu.edu.tr

Orcid ID: https://orcid.org/0000-0002-6969-1570

\section{Serife BILINiNiR}

Arş. Gör., Kahramanmaraş Sütçü İmam Üniversitesi, Fen Edebiyat Fakültesi, Coğrafya Bölümü, serifebilinir@ksu.edu.tr

Orcid ID: https://orcid.org/0000-0002-7135-3984

\section{Öz}

İnsanlar şehir hayatının tempolu, yoğun ve bunaltıcı ortamından kendilerini bir ölçüde uzaklaştırmak, dinlenmek, eğlenmek, eğitim, sağlık, merak, zevk, spor, dini, kültürel vb. sebeplerle bireysel veya toplu olarak belli bir zaman diliminde turizm faaliyetlerine katılmaktadırlar. Termal turizm de bu turizm faaliyetlerinden birisidir. Bu çalışmada Kahramanmaraş ilinde yer alan ve termal turizm açısından önem taşıdığı düşünülen Döngele Kaplıcası incelenmektedir. $\mathrm{Bu}$ çalışmada amaç, Döngele Kaplıcasının turizm potansiyelini belirlemek, yöre için ne anlam ifade ettiğini açıklamak ve turizm için mevcut potansiyelin en iyi şekilde nasıl değerlendirilmesi gerektiğini ortaya koymaktır. Bu amaç doğrultusunda yöre halkına ve tesislere gelen ziyaretçilerle anket çalışması gerçekleştirilmiştir. Anket verileri frekans dağılımı yöntemi ile analiz edilmiştir. Arazi çalışmalarının da gerçekleştirildiği bu çalışmada, elde edilen veriler de dikkate alınarak çeşitli haritalar ArcMap 10.3 paket programı kullanılarak üretilmiştir. Ayrıca arazi çalışmaları, anket ve mülakat sonuçları dikkate alınarak yörede turizmin geliştirilmesi konusunda önerilerde bulunulmuştur.

\footnotetext{
${ }^{1}$ Makale Geliş/Kabul Tarihi: 05.08.2019 / 16.10.2019

Künye Bilgisi: Karademir, N., Sandal, E. K., Bilinir, Ş. (2019). Döngele Kaplıcası (Kahramanmaraş)'nın Termal Turizm Potansiyeli ve Sosyo-Ekonomik Katkıları. Kahramanmaraş Sütçü İmam Üniversitesi Sosyal Bilimler Dergisi, 16 (2), 640-670. DOI: 10.33437/ksusbd.601710
} 
Anahtar Kelimeler: Kahramanmaraş, Döngele Kaplıcaları, Termal Turizm.

\title{
Döngele Hot Springs (Kahramanmaras) Thermal Tourism Potential and Its Socio-Economic Contributions
}

\begin{abstract}
People participate in tourism activities individually or collectively for a certain period of time due to reasons such as moving away from the brisk, intense and overwhelming environment of city life, resting, having fun, having education, health, curiosity, pleasure, sports, religious, cultural and similar reasons. Thermal tourism is one of these tourism activities. In this study, Döngele is considered to be important for thermal tourism and located in Kahramanmaras province. The purpose of this study is to determine the tourism potential of Döngele spa, to explain what it means for the region and to show how the potential for tourism should be evaluated in the best way. For this purpose, surveys were carried out to visitors from the locals and facilities in the region. Survey data were analyzed by frequency distribution method. In this study where field works were carried out, various maps were produced using Arc Map 10.3 package program considering the data obtained. In addition, suggestions were made on the development of tourism in the region by taking into account the results of field studies, questionnaires and interviews.
\end{abstract}

Keywords: Kahramanmaras, Döngele Hot Springs, Thermal Tourism.

\section{GİRIŞ}

Turizm, genel olarak bireylerin dinlenme, eğlenme, eğitim, sağlik, merak, zevk, spor, dini, kültürel vb. sebeplerle bireysel veya toplu olarak belli bir zaman diliminde bu sektörün unsurlarından yararlanarak yaptıkları faaliyetlerdir. İnsanlar seyahatlerini daha ilkçağlardan itibaren gezip-görmek, şifa bulmak, dini ve toplumsal etkinliklere katılmak için yapmışlardır. Coğrafi keşifler ve endüstri devrimi ile beraber bu etkinlikler artmış, gelişen eğitim ve artan refah seviyesi turizm kavramını ve faaliyetini ortaya çıkarmıştır. 1950'lerden sonra ise, ulaşım ve iletişim alanındaki dikkat çeken gelişmeler, teknolojinin ve devletlerarası ilişkilerin gelişmesine bağlı olarak artan mal ve hizmet dolaşımları, ülkelerin birbirine olan iktisadi bağımlılıkları ve insanların gelir düzeylerinin artması gibi nedenlerle turizm ekonomik ve sosyo-kültürel anlamda giderek artan ve gelişen bir sektör haline dönüşmüştür (Yereli ve Kara, 2012; Karataş ve Babür, 2013).

Günümüzde milyonlarca insan sürekli olarak yaşadıkları yerlerden geçici süreler için başka yerlere gitmekte ve toplumun gözünde turizmin önemi gün 
geçtikçe artmaktadır. Hem ekonomik büyüklüğü hem de toplumsal etkileriyle turizm, dünyada çok önemli bir rol oynamaktadır. Turizm, artan insan ihtiyaçları, gelişen teknolojik olanaklar vb. faktörler ile sürekli bir değişim içindedir. Yakın zamana kadar turizm faaliyetlerine katılan insanların amacı genelde yeni yerler görmek, doğal güzellikleri gezmek, denize girmek gibi faktörlerden oluşmakta iken günümüzde bu faktörlere hastalıkların tedavisi için, o ülkenin iklim ve hava şartları ile yeraltı kaynaklarından sağlık amaçlı faydalanarak iyileşmek ve sağlıklı bir yaşam sürmek eklenmiştir (Edinsel ve Adıgüzel, 2014; İpar ve Tırıl, 2014).

Sağlık turizmi, insanların yaşadıkları yerden değişik bölge ve ülkelere, sağlıklı olmak ve rehabilitasyon amacıyla gerçekleştirdikleri bir turizm çeşididir. Çok geniş bir alanı kapsayan sağlık turizmi birçok çeşide sahiptir. Bunlar; termal turizm, güzellik ve zindelik (SPA, Wellness) turizmi ve medikal turizm ya da tedavi amaçlı sağlı turizmidir (Özkurt, 2007; Edinsel ve Adıgüzel, 2014). Farklı bir araştırmada ise sağlık turizmi, termal turizm, SPA-Wellness, medikal turizm ve ileri yaş turizmi olarak çeşitlendirilmiştir (Zengingönül vd., 2012).

Sağlı turizminin en eski türü olan termal turizmin geçmişi M.Ö. 1700'lü yıllara dayanır. Hipokrat gibi dönemin tıp otoriteleri tarafindan bu tür kaynakların iyileştirici etkisi olduğu ifade edilmiştir. Bundan dolayıdır ki başta Roma ve Yunan olmak üzere birçok medeniyette banyo ve masaj kültürü gelişmiştir. Bu bölgelerde yaşayan krallar, aristokratlar ve halk güzelleşmek ve sağliklarına kavuşmak için hamamlar-havuzlar yaptırmışlardır. Görülen o ki antik dönemlerden itibaren insanlar şifalı suları kullanmakta ve sağlıklarına kavuşmak için seyahatler yapmaktadır. Günümüze kadar bu turizm türü, sağl1k turizminin en tanınmış türü olmaya devam etmiştir. Bugün termal turizm, genellikle tıbbi tedavilerin tamamlayıcısı veya alternatif bir tıp metodu olarak görülmektedir. Ürün ve hizmet çeşitlendirmesi açısından değerlendirildiğinde ise sağlık turizmi kapsamında oldukça yüksek oranlarda ekonomik gelir kaynă̆ına sahip bir alt sektör durumundadır (Sucu, 1990; Zengingönül vd., 2012).

Termal turizm ise, sıcak ve soğuk minarelli suların sağlik amacıyla içme ve dış tatbiklerle kullanımı için turistlerin ulaşım, konaklama ve ağırlama gereksinimlerinin karşılanmasını kapsayan bir turizm türüdür. Halk arasında şifalı sular olarak tanımlanan bu kaynaklardan içilenlere içme veya içmece, dış tatbikler ile kullanılanlarına ise ılıca, girme, çermik, hamam, kaynarca, ılısu gibi isimler verilmektedir. Turizm literatüründe ise kaplıca merkezi veya termal merkez olarak adlandırılmaktadır (Doğaner, 2001).

Termal suların kaplıcada kullanılabilmesi için yeraltından çıkan doğal termal su olması, çıkış noktasında sıcaklığının $20^{\circ} \mathrm{C}$ üzerinde olması ve litresinde ise en az 1 gram mineral bulunmas 1 gerekmektedir. Diğer bir ifade ile bir yer altı suyuna şifalı su denilmesi için 1 litresinde en az 1 gram mineral ve eşit değerler üzerinde 
karbondioksit, hidrojen sülfür ve radon gazlarından en az birinin bulunmas1 gerekir. Termal sular, yeryüzünün derinliklerinden gelen, farmakolojik etkiye sahip, bakteriyolojik ve kimyasal kirlenmeye uğramamış, mineral tuzlar, oligoelementler, 1s1 derecesi gibi belirgin özellikleri bulunan sulardır. Termal sular mineral yoğunluklarına göre (1 litrede mg. miktarına göre) sınıflandırılır. Çok az mineral içeren sular: $50 \mathrm{mg} / \mathrm{lt}$, az mineral içerikli sular: 50 - $500 \mathrm{mg} / \mathrm{lt}$, orta derecede mineralli sular: $500-1500 \mathrm{mg} / \mathrm{lt}$., çok zengin mineral içerikli sular ise: $1500 \mathrm{mg} / \mathrm{lt}$. şeklinde kategorize edilir. Termal suların sağlık açısından birçok faydası bulunmaktadır. Bikarbonatlı sular hazmı kolaylaştırır, damarlardaki baskıyı azaltır, idrarı artırır ve metabolizmayı canlandırır. Diğer yandan sülfürlü yani kükürtlü sular kan dolaşımını ve sinir sistemini uyarırken, sülfatlı sular ciltte, eklemlerde ve sindirim organlarında etkilidir. Ayrıca yine bir termal su çeşidi olan demirli sular ise bağırsak tembelliğinin giderilmesinde etkilidir (Mergen vd., 2006; Çevre Sağlı̆̆1, 2011).

Kaplica ise, termal sulardan faydalanmak için kaynakların çevresinde kurulan sağlık tesisleridir. Kaplıcanın bulunduğu yerin iklimi, yerel radyasyon özellikleri, havanın sıcaklık ve nem oranı, basıncı, rüzgâr özellikleri ve elektriksel iyon yoğunluğu, kürün vücut üzerindeki özel etkilerinde değişiklikler yapar. Termal suyun kaynağı çevresinde bulunan bitki örtüsü ve hayvan toplulukları, suyun fiziksel ve kimyasal değişime uğramasına sebep olur. Kaplıca tedavisi, sıcak, madensel yeraltı sularının tedavi edici etkilerinden, banyo veya kısmi banyo şeklinde faydalanmadır. Kaplıca tedavilerinde uygulama türleri, sıcak su banyoları, sauna, jet duş, masaj, buhar banyosu, çamur tedavisi, güneşlenme ve iklim tedavileridir. Buralardan kireçlenmeler, iltihaplı romatizmalar, yumuşak doku romatizmaları, mekanik bel ve boyun problemleri, çalışma şart ve ortamına bağlı ağrılı tablolar, ortopedik problemler (kırık sekelleri, ameliyat komplikasyonları vb.), spor yaralanmaları, kas hastalıkları, nörolojik hasarlanmalara bağlı problemler gibi rahatsızlıkların tedavisinde yararlanılır (Mergen vd., 2006; Çevre Sağlığı, 2011). Sağlık turizmi açısından kaplıcalar oldukça önemli yerlerdir. Türkiye, doğal kaynakları, iklimi, zengin ve geleneksel kültürel yapısı ve kaplıcaları yönünden dünyanın zengin yerlerinden birisidir. Çok sayıda ve üstün nitelikler taşıyan termal kaynaklara sahiptir. Günümüzde insanların kaplıcalara büyük oranda ilgi duyması ve bunlardan yararlanmas1 ülkemizde iç turizmin gelişmesine katkıda bulunmaktadır (Sucu, 1990). Bu nedenlerden dolayı termal turizm üzerinde durulması gereken önemli konulardan biridir.

Neojen ve Kuvaterner dönemlerinde Türkiye'de, meydana gelen kıvrılma ve kırılmalar sonucunda yüzlerce termal kaynak ortaya çıkmıştır. Genellikle kırıklı yapıların yer aldığ alanlarda dağılış gösteren termal kaynaklardan (kaplıca, 1lıca, çermik), içmeler ve maden sularından insanlar tarih boyunca çeşitli şekillerde faydalanmışlardır (Özgen, 2010). Araştırma sahamızı oluşturan Döngele ve 
çevresi ise Kahramanmaraş fay zonunun bulunduğu Miyosen yaşlı kırıntılar ve karbonatlı çökeller üzerinde yer almaktadır. Yörede termal su kaynakları bu zondan çıkmakta ve bu araştırmanın konusunu sağlık turizminin bir çeşidi olan termal turizm oluşturmaktadır.

Türkiye, termal kaynaklar bakımından oldukça zengin bir ülkedir. Ayrıca ülkemiz mevsimlere bağlı kalmaksızın, tüm yıl boyunca termal turizmi gerçekleştirilebilecek bir potansiyele sahiptir (Erdoğan ve Aklanoğlu, 2008). Fakat ülkemiz yeterli potansiyele sahip olmasına rağmen termal turizmden tam anlamıyla yararlanılamamaktadır.

Termal turizm kaynakları bakımından Kahramanmaraş ili önemli bir potansiyele sahiptir. Onikişubat ilçe sınırları içerisinde yer alan Döngele Kaplıcası da sağlık turizmi açısından büyük bir önem taşımaktadır. Söz konusu kaplıca hem bugün hem de gelecek için önemli bir termal turizm potansiyeli niteliğindedir.

\section{AMAÇ VE ÖNEM}

1991 yılında Sır Barajının yapılması ile sular altında kalan Döngele Kaplıcası, uzun yıllar atıl durumda kalmıştır. Bu nedenle birtakım gerileme süreçleri içerisine girmiş ve eski önemini zamanla kaybetmiştir. Söz konusu kaplıca son yıllarda özel sektörlerin desteği ile yeniden geliştirilmeye çalışılmaktadır. Bu araştırmada, Döngele Kaplıcasının sağlıkla ilgili hangi amaçlar doğrultusunda kullanıldığı incelenmiştir. Ayrıca yörede yürütülen geleneksel kaplıca tedavisi uygulamalarının özellikleri ele alınmıştır. Çalışma kapsamında, kaplıca tedavisi uygulamaları için tesislere gelen kişilerin kaplıca ile ilgili düşünceleri öğrenilmeye çalışılmıştır. Ayrıca yöre halkının da kaplıcanın işlevsel hale gelmesinden nasıl etkilendikleri araştırılmışıtır. Elde edilen sonuçlar doğrultusunda Döngele Kaplıcasının, Türkiye'deki termal turizm değerinin arttırılması hedeflenmiştir.

Araştırmada, Kahramanmaraş Döngele Kaplıcasının termal turizm potansiyeli üzerinde durulmuş, termal turizmin gelişmesi ve tam anlamıyla uygulanması, diğer turizm türleriyle birlikte yapılmasına yönelik öneriler geliştirilmiştir. Çalışmanın yapılmasındaki en önemli etkilerden biri sağlık turizmine dair literatür incelendiğinde, Döngele Kaplıcasına yönelik herhangi bir çalışmanın bulunmaması ve literatürdeki bu boşluğun doldurulmasıdır. Bu çalışmanın en etkili yönlerinden birisi de, Döngele Kaplıcalarının bulunduğu yerde yaşayan halka ve tesislere gelen ziyaretçilere, kaplicayla ilgili düşüncelerini ortaya koyabilmek için araştırmacılar tarafindan hazırlanan anket uygulaması gerçekleştirilmesidir. Yapılan bu uygulama iki ayrı grubun yöre ile ilgili düşüncelerini karşılaştırma imkânı sunmaktadır. 


\section{YÖNTEM}

Araştırmada öncelikle konu ile ilişkili yerli ve yabancı kaynaklar taranmıştır. Daha sonra araştırma alanına gidilerek saha çalışmaları yapılmışıı. Bu çalışmalar sırasında Döngele Kaplıcalarının bulunduğu yerde yaşayan halka ve tesislere gelen ziyaretçilere, kaplıcayla ilgili düşüncelerini ortaya koyabilmek için araştırmacılar tarafindan hazırlanan anket uygulaması gerçekleştirilmiştir. Ayrıca anket sorularının anlaşılır olup olmadığının tespiti için yörede yaşayan halktan ve ziyaretçilerden bir gruba ön anket uygulaması yapılarak, anlaşılması zor olan sorular üzerinde gereken düzenlemeler yapılmış ve veri toplama aracı olan anketler son haline getirilmiştir. Yapılan araştırmada, yöre halkına yapılan anket araştırmasının evreni 2006 kişi (2017 yılı Döngele nüfusu) olup, örneklem grubunu yörede yaşayan halktan 129 kişi oluşturmaktadır. Tesislere gelen ziyaretçilere yapılan anket çalışmasının evrenini yaklaşık 4000 kişi (tesislerin günlük kapasitesi) oluştururken örneklemi 147 kişidir. Bu araştırma 2018 y1lı Haziran ve Temmuz aylarında kaplıcayı ziyarete gelen ve rassal olarak seçilen katılımcılara yapılmıştır. Sonrasında SPSS paket programı kullanılarak anket verileri Frekans Dağılımı ile analiz edilmiştir. Arazi çalışması yapılmış, ArcMap 10.3 paket programı kullanılarak yörenin lokasyon, fiziki ve jeoloji haritaları üretilmiştir. Ayrıca yörede otel işletmecileri, yerel yöneticiler ve mülkî idare yetkilileri ile mülakatlar yapılmıştır.

\section{BULGULAR}

\section{Araştırma Sahasının Coğrafi Konumu}

Araştırmamıza konu olan Döngele Kaplıcası, yine aynı adı taşıyan Döngele Mahallesi sınırları içinde bulunmaktadır. Mahalle, Kahramanmaraş İli Onikişubat İlçesine bağlıdır. Kahramanmaraş'a $40 \mathrm{~km}$ mesafede bulunan Döngele Mahallesi, Ceyhan Nehri üzerinde bulunan Sır Barajının batısında yer almaktadır. Mahallenin batısında Andırın İlçesi ve güneyinde Osmaniye İlinin Düziçi İlçesi, batısında Rahmacılar Mahallesi, güneyinde Yolyanı Mahallesi ve kuzeyinde Yenicekale Mahallesi bulunmaktadır (Şekil 1). 


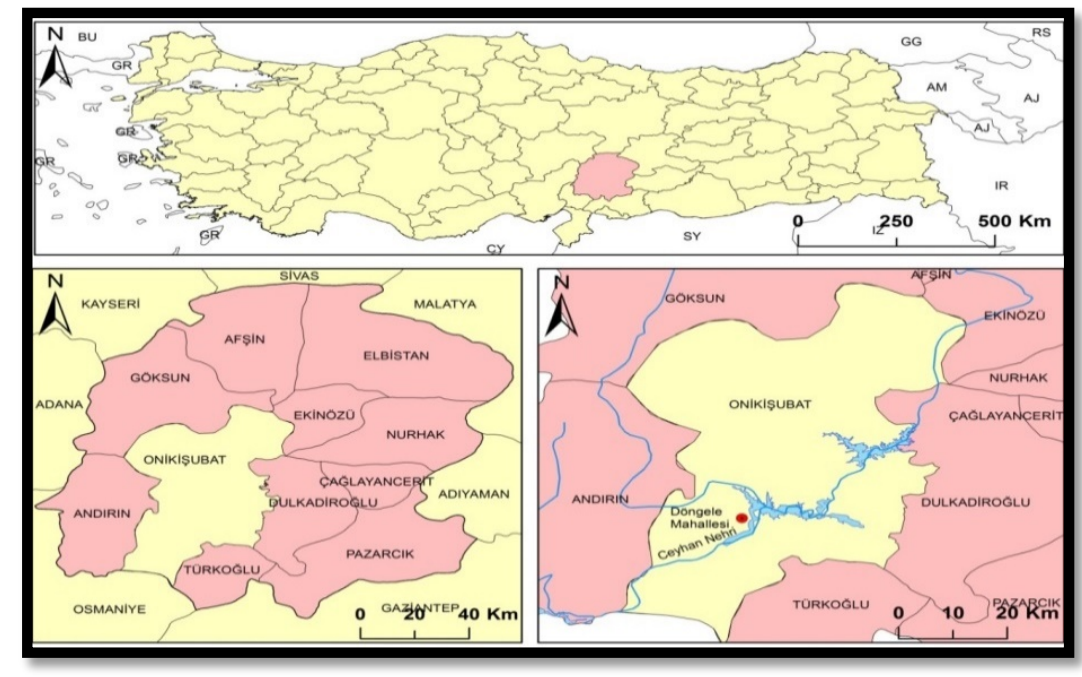

Şekil 1. Çalışma alanının lokasyon haritası.

\section{Fiziki Coğrafya Özellikleri}

Araştırma sahası ve yakın çevresinin yükseltisi yer yer 2.000 m.'ye ulaşmaktadır. Bu yükselti genellikle Güneydoğu Torosların uzantıları olan dağlarla, bunlar arasında kalan çöküntü ovalarından oluşmaktadır. Kahramanmaraş topraklarında geniş bir akarsu ağı bulunmakla birlikte birçok yer bu akarsuların oluşturduğu vadilerle yarılmış ve parçalanmıştır. Afrika Göller Bölgesi'nden başlayarak, Kızıldeniz, Lut Gölü ve Amik Ovası boyunca uzanan Ürdün Graben sisteminin devamı olan ve çalışma alanının doğu kısmını oluşturan bu alan Amik-Kahramanmaraş oluğu adıyla anılmaktadır. Dağlar ise Kahramanmaraş topraklarının \%59,72'sini kaplamaktadır. Söz konusu alanı engebeli bir şekle sokan dağlar, genel olarak Güneydoğu Toroslar'ın uzantısıdır. Kahramanmaraş'ın kuzeyinde yükselti gittikçe artmaktadır. Araştırma sahasının batısında bulunan Başkonuş dağı $1779 \mathrm{~m}$. iken kuzeydoğuda Berit dağında yükselti 3027 m. yi bulmaktadır. Sahanın doğusunda Sır Barajı (Ceyhan Nehri) ve Güneyinde Kıble Dağı bulunmaktadır. Geniş bir akarsu ağına sahip olan il toprakları, Türkiye'nin önemli akarsularından biri olan Ceyhan Nehrinin de doğduğu yerdir. Menzelet Barajı ve Sir Barajı Ceyhan nehri üzerinde kurulmuştur. Araştırma sahasının doğusunda ise Maraş ovası yer almaktadır (Şekil 2). 


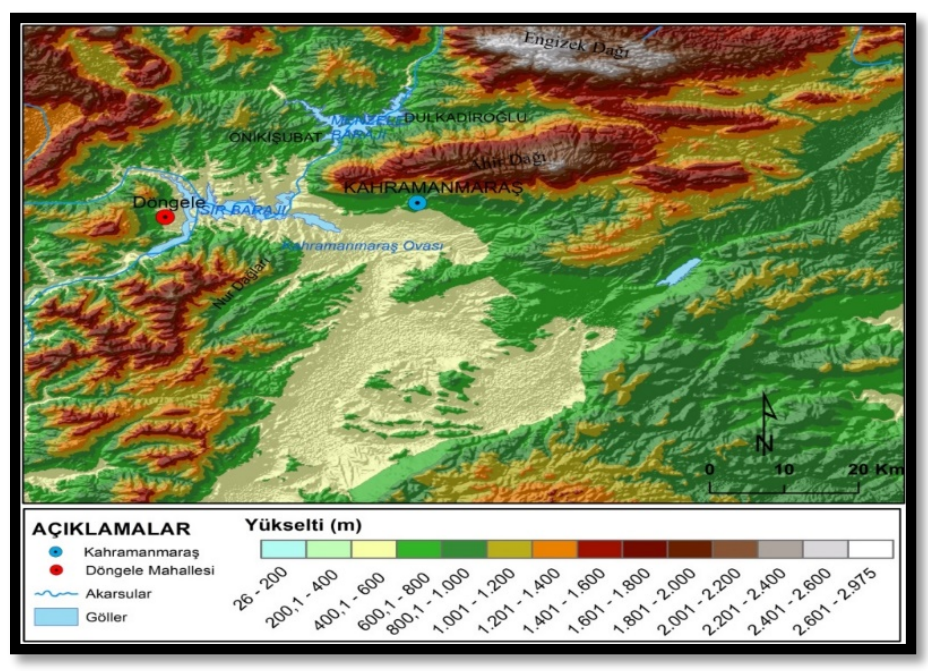

Şekil 2. Çalışma alanı ve yakın çevresinin topoğrafya haritası.

\section{Termal Suların Fiziksel ve Kimyasal Özellikleri}

Şifalı sular ya da kaplıcalar bulundukları yerlerin jeolojik yapısına, kaynak türlerine, bileşenlerine, sıcaklıklarına, $\mathrm{pH}$ ve sertlik derecelerine, radyoaktif özelliklerine, sağlı açısından etkili oldukları hastalıkların türlerine vb. özelliklere bağlı olarak sınıflandırılabilirler. Kahramanmaraş ilindeki kaplıcalar sıcaklıklarına göre değerlendirildiğinde bunlardan Ilıca, Yeldeğirmeni ve Döngele kaynaklarının sularının "sıcak şifalı sular" $\left(20^{\circ} \mathrm{C}\right.$ 'nin üstünde) kapsamına girdiği görülmektedir (Uslu ve Kaya, 2015).

Kahramanmaraş’taki Döngele Kaplıcasının geçmişinin binlerce yıl öncesine dayandığı görülmektedir. Suyu içilebilir kalitede ve şifalı olması nedeni ile oldukça ilgi çekmektedir. Önemli bir konuma ve kapasiteye sahip olan Hartlap sıcak su kaynağı da denilen Döngele Kaplıcası, 1991 yılında Sır Barajının yapılması ile sular altında kalmıştır. Baraj yapımından önce, Ceyhan Nehri'nin batı yakasındaki Döngele Mahallesi ile aynı tarafta bulunması nedeniyle sıcak su Döngele olarak adlandırılmıştır. Kaplıca suları baraj altında kaldıktan sonra özel yatırım teşebbüsleri sayesinde 01.01.2010 tarihinde jeotermal kaynak tekrar yeryüzüne çıkarılmaya başlanmıştır. Sağlık turizmi açısından önemli bir yere sahip olan bu kaplıcaların su sıcaklığ ortalama $38 \mathrm{C}^{\circ}$ dir. Alanda yapılan sondaj çalışmaları sonucunda 370 metre derinlikte yaklaşık 100 lt/sn debiye sahip kaynağa ulaşılmıştır (Alpman, 1964; Kop, 2010). Termal suyun bünyesinde; sodyum, potasyum, amonyum, magnezyum, kalsiyum, mangan, demir, klorür, 
bromür, hidrojen sülfür, bikarbonat, fosfat ve florür bulunmaktadır (Tablo 1). Bu sıcak su kaynağı yöredeki tesislerin ihtiyacını karşılayabilecek düzeydedir. Ayrıca bölgede yeni kuyuların açılması için etüt çalışmaları da devam etmektedir. Günümüzde yapılan çalışmalar sonucunda yeniden faaliyete geçirilen kaplıca, yörede gittikçe artan bir ilgi görmektedir.

Tablo 1: Jeotermal kaynağın kimyasal özellikleri.

\begin{tabular}{|l|l|l|l|}
\hline Kimyasal Özellikler & $\mathrm{mg} / \mathrm{L}$ & $\mathrm{meg} / \mathrm{L}$ & \% milival \\
\hline Sodyum & 25.1 & 1.09 & 16.0 \\
\hline Potasyum & 3.15 & 0.08 & 1,0 \\
\hline Amonyum & $<0.05$ & - & - \\
\hline Magnezyum & 32.2 & 2.68 & 39.0 \\
\hline Kalsiyum & 60.6 & 3.03 & 44.0 \\
\hline Mangan & $<0.0005$ & - & - \\
\hline Demir & 0.021 & - & - \\
\hline Florür & 0.57 & - & - \\
\hline Klorür & 18.4 & 0.52 & 7.5 \\
\hline Bromür & $<0.2$ & - & - \\
\hline İyodür & 0.001 & - & - \\
\hline Nitrit & $<0.05$ & - & - \\
\hline Nitrat & 1.58 & 0.03 & 0.4 \\
\hline Sülfat & 12.6 & 0.26 & 3.8 \\
\hline Bikarbonat & 371.49 & 6.09 & 88.3 \\
\hline Hidrojen sülfür & $<0.01$ & - & - \\
\hline Fosfat & $<0.4$ & - & - \\
\hline
\end{tabular}

Kaynak: Çakar, 1996.

Döngele Kaplıca suyunun kimyasal özellikleri ile ilgili çalışmalar 2009 yılında Refik Saydam Hıfzıssıhha Merkezi Başkanlığı tarafından yapılmıştır. Kaplıca suyu, romatizmal hastalıklara, kemik erimesi, siyatik, bel-boyun fitığ kireçlenme, böbrek hastalıkları, dolaşım sistemi hastalıkları, sindirim sistemi rahatsızlıkları, cilt hastalıkları, nörolojik iyileştirme gerektiren hastalıklar ve kemik erimesinde kalsiyum tamamlayıcı tedavisine faydalıdır. Bunların yanı sıra ameliyat sonrası tutukluk ve sertliklerin giderilmesi, kadın hastalıkları, stres ve strese bağlı tüm hastalıkların iyileştirilmesi, uykusuzluk ve yorgunluklar, saç, tırnak ve derideki hücrelerin canlanması, mide ve yemek borusu rahatsızlıklarına da iyi geldiği belirtilmektedir (http://termalrehber.com/kahramanmaras-ili-sifalisulari-ve-kaplicalari). 


\section{Jeolojik Özellikleri}

Çalışma sahası, Arap Levhası ile Anadolu Levhası'nın çarpışma kuşağında ve Anadolu Levhası üzerinde yer almaktadır. Söz konusu levhaların Kretase'de çarpışması sonucunda kuzey-güney yönlü birçok kıvrılma-kırılma-bindirme ve sürüklenmelerin oluşmasında etkili olmuştur. Kahramanmaraş havzasında Paleozoyik'ten günümüze kadar uzanan yaş aralığında çökelmiş birçok birim bulunmaktadır. Bölgede yüzeylenen birimler, Eosen-Oligosen dönemine ait çökelleri bünyesinde barındıran, tektonik olarak oldukça aktif Doğu Toroslar bölgesinde yer almaktadır (Gül vd., 2005; Babaoğlu, 2008; Varol vd., 2012) (Şekil 3).

Döngele civarında yaşlıdan gence doğru sırasıyla; Devoniyen yaşlı Suar formasyonunun Şarlakdere üyesi, Üst Triyas yaşlı Kürecik formasyonu, Üst Triyas-Jura-Kretase yaşlı Eloğlu formasyonu, Eosen yaşlı Midyat formasyonu, Orta Miyosen yaşlı Yenicekale formasyonunun Parpiyayla ve Döngele üyeleri ve Pliyosen yaşlı Gölbaşı formasyonu gibi litostratigrafi birimleri bulunmaktadır. Jeolojik olarak oldukça karmaşık olan bölgede birçok olumsuzluk bulunmasına rağmen bu karmaşık yapı, aynı zamanda Kahramanmaraş ve civarına önemli kazanımlar da sunmaktadır. Bölgedeki sıcak su kaynakları ve bu kaynaklara ilişkin potansiyel olan jeotermal alanların varlığı bu kazanımların en başında gelmektedir (Kop, 2010).

Döngele Kaplıcasının suları, Miyosen yaşlı kırıntılar ve karbonatlılar üzerinde ve Kahramanmaraş fay zonunun olduğu bölgeden çıkmaktadır. Araştırma sahasında, fayın büyük bir kısmı Sır Barajı altından kuzeybatıya doğru devam etmektedir. Yamaçlardaki yüksek erozyonun oluşturduğu karasal Kuvaterner sedimanlar tarafindan örtülmesinden dolayı fayın karada olan diğer bölümü de belirgin değildir. Döngele Kaplıcasının sıcak su kaynakları, Eosen yaşlı konglomera, kumtaşı, silttaşı ve kireçtaşı birimleri ile bunların üzerine diskordan olarak gelen Orta Miyosen yaşlı kireçtaşı, kumtaşı, kalker, yumrulu çamurtaşı ve konglomeralardan oluşan birimlerin içerisinden NW-SE yönlü bir faydan çıkmaktadır. Yörede çıkan su kimyasal özellikler bakımından akroterm termal su sınıfına girmektedir (Alpman, 1964; Baydar ve Yergök, 1996; Kırdan,2004) (Şekil 3). 


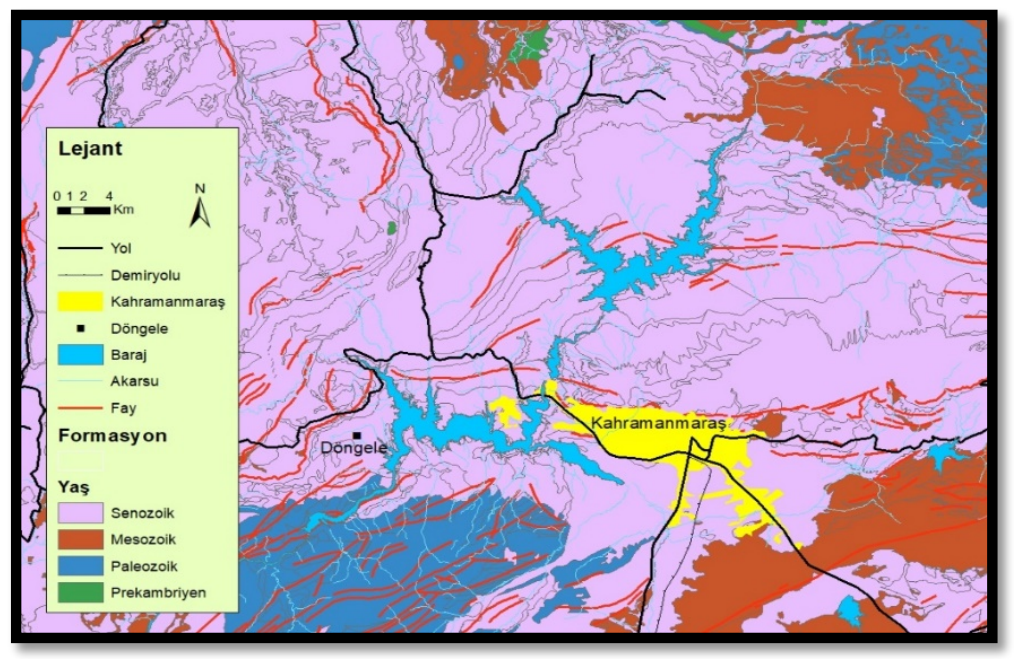

Şekil 3. Çalışma alanı ve yakın çevresinin jeoloji haritası.

\section{İklim ve Bitki Örtüsü}

Yörede yazları sıcak ve kurak, kışları serin ve yağışlı Akdeniz iklimi görülür. Fakat yükseltiyle ilişkili olarak iklim değerlerinde ve iklim elemanlarında değişiklikler görülebilir. Yörenin yıllık ortalama sıcaklığ $16^{\circ} \mathrm{C}$ derecedir. Y1llık yăğş miktarı ise metrekareye $733 \mathrm{~mm}$ civarındadır. Aylık ortalama sicaklık değerleri incelendiğinde $28{ }^{\circ} \mathrm{C}$ ile en sicak aylar Temmuz ve Ağustos iken, en soğuk ay sıcaklık derecesinin $4{ }^{\circ} \mathrm{C}$ dereceye kadar düştüğü Ocak ayıdır. Araştırma sahasında yalnızca toplam yağışın \%3'ü yaz mevsiminde düşmektedir. $\mathrm{Bu}$ alandaki kış yağışları yükseltinin ve karasallığın etkisine bağlı olarak bir kısmı kar şeklinde görülür. Kar yağışları genellikle Kasım ayının sonunda başlamakla birlikte kar örtüsü yüksek kesimlerde Mart ayına kadar yerde kalmaktadır (Tablo 2, Şekil 4). Genel itibarı ile yörenin iklimi yılın her mevsiminde termal turizm imkânı sağlamaktadır.

Tablo 2. Kahramanmaraş'ın aylık ve yıllık ortalama sıcaklık ve yağış değerlerinin dağılımı.

\begin{tabular}{|c|c|c|c|c|c|c|c|c|c|c|c|c|c|c|}
\hline İstasyon & & $\mathbf{O}$ & Ş & M & $\mathbf{N}$ & M & H & $\mathbf{T}$ & A & E & $\mathbf{E}$ & $\mathbf{K}$ & A & Yillık \\
\hline K.mara & \begin{tabular}{|l} 
Sicaklık \\
$\left({ }^{\circ} \mathbf{C}\right)$
\end{tabular} & 4,8 & 6,3 & 11 & 15 & 2 & $\begin{array}{l}25, \\
2\end{array}$ & $\begin{array}{l}28, \\
3 \\
\end{array}$ & \begin{tabular}{|l}
28, \\
4
\end{tabular} & $\begin{array}{l}25, \\
2,\end{array}$ & 19 & $\begin{array}{l}11, \\
7\end{array}$ & 6,6 & 16,8 \\
\hline Ş & $\begin{array}{l}\text { Yağıș } \\
(\mathbf{m m})\end{array}$ & 129,6 & 114 & 96 & 76 & 41 & 6,6 & 1,2 & 0,9 & 7,4 & $\begin{array}{l}46, \\
9\end{array}$ & \begin{tabular}{|l}
85 \\
2
\end{tabular} & $\begin{array}{l}12 \\
9 \\
\end{array}$ & 733,7 \\
\hline
\end{tabular}




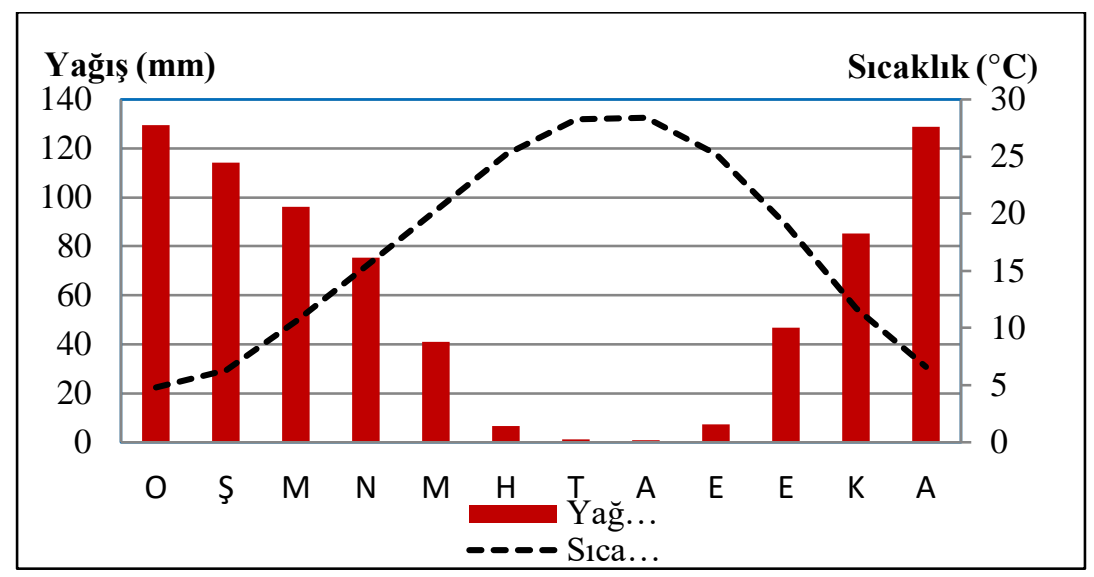

Şekil 4. Kahramanmaraş'ın aylık ve yıllık ortalama sıcaklık ve yağış değerlerinin dağılımı.

Araştırma sahası, İran-Turan ve Akdeniz bitki coğrafyası bölgelerinin geçiş kuşağında bulunmaktadır. Topografya, iklim ve toprak derinliğinde gözlenen farklılaşmalardan dolayı bitki tür ve yoğunluğunda değişimler gözlemlenmektedir. Söz konusu sahada, orman alanları geniş yer kaplamaktadır. Özellikle toprak örtüsünün zayıf olduğu kalkerli zeminlerde kızılçam (Pinus brutia) ve ardıç (Juniperus excelsa) geniş bir alanda yayılış göstermektedir. Bunlara, bazı yerlerde meşe (Quercussp.) türleri ve tesbih çalısı (Styrax officinalis) eşlik etmektedir (Varol, 2003; Sandal ve Karademir, 2015; Ortaç, 2017). Yörenin bitki örtüsünün yoğunluğu ve orman alanlarının genişliği termal turizme ayrı bir avantaj sağlamaktadır. Tesislere gelen ziyaretçilere doğa ile iç içe olma imkanı sağlamakla birlikte, yöreye ayrı bir çekicilik kazandırmaktadır.

\section{Nüfus ve Yerleşme Özellikleri}

Araştırma sahasının nüfus özellikleri incelendiğinde, 1935 yılından 2000 yılına kadar nüfusun hızlı bir şekilde arttığı gözlemlenmektedir. 1935 yılında 697 kişi olan nüfus 1955 yllında 1042'ye yükselmiştir. 1975 yllında 2251 kişi olan mahalle nüfusu, 1990'da 3297'lere ulaşmıştır. 2000 yılı nüfus sayımında ise 3783 olan Döngele Mahallesinin nüfusu, bu tarihten sonra gittikçe düşerek 2017 yılında 2006'ya inmiştir (Tablo 3). Nüfustaki azalmaların genel olarak, termal suyun Sır Barajı altında kalması, yöredeki idari değişimden ve nüfusun yeterince istihdam edilememesinden kaynaklandığı düşünülmektedir.

Tablo 3: Döngele'nin yıllara göre nüfusu.

\begin{tabular}{|l|l|l|l|}
\hline Yıllar & Toplam Nüfus & Yıllar & Toplam Nüfus \\
\hline $\mathbf{1 9 3 5}$ & 697 & 1980 & 2555 \\
\hline
\end{tabular}




\begin{tabular}{|l|l|l|l|}
\hline $\mathbf{1 9 4 0}$ & 710 & 1985 & 2741 \\
\hline $\mathbf{1 9 4 5}$ & 800 & 1990 & 3297 \\
\hline $\mathbf{1 9 5 0}$ & 859 & 2000 & 3783 \\
\hline $\mathbf{1 9 5 5}$ & 1042 & 2007 & 2632 \\
\hline $\mathbf{1 9 6 0}$ & 1082 & 2010 & 2526 \\
\hline $\mathbf{1 9 6 5}$ & 1307 & 2014 & 2153 \\
\hline $\mathbf{1 9 7 0}$ & 1702 & 2016 & 2070 \\
\hline $\mathbf{1 9 7 5}$ & 2251 & 2017 & 2006 \\
\hline
\end{tabular}

Kaynak: TÜíK (2018)

2012 y1lına kadar belediye statüsünde olan Döngele Kahramanmaraş'ın büyükş̧ehir statüsüne kavuşmasından sonra Onikişubat ilçesine bağlı bir mahalle statüsüne geçmiştir. Sır Barajı altında kalan termal su kaynağının 2010 yılında yeniden yüzeye çıkarılması ile yörede turizm yatırımları artmaya başlamıştır. $\mathrm{Bu}$ çerçevede yerleşmeye, günlük 4.000 kişiye hizmet sağlayabilecek günübirlik tesisler alanı, apartlar ve 4 adet büyük otel yatırımı yapılmıştır. Yöreye yapılan bu tesisler geniş kapasiteli ve modern tesislerdir (Fotoğraf 1).
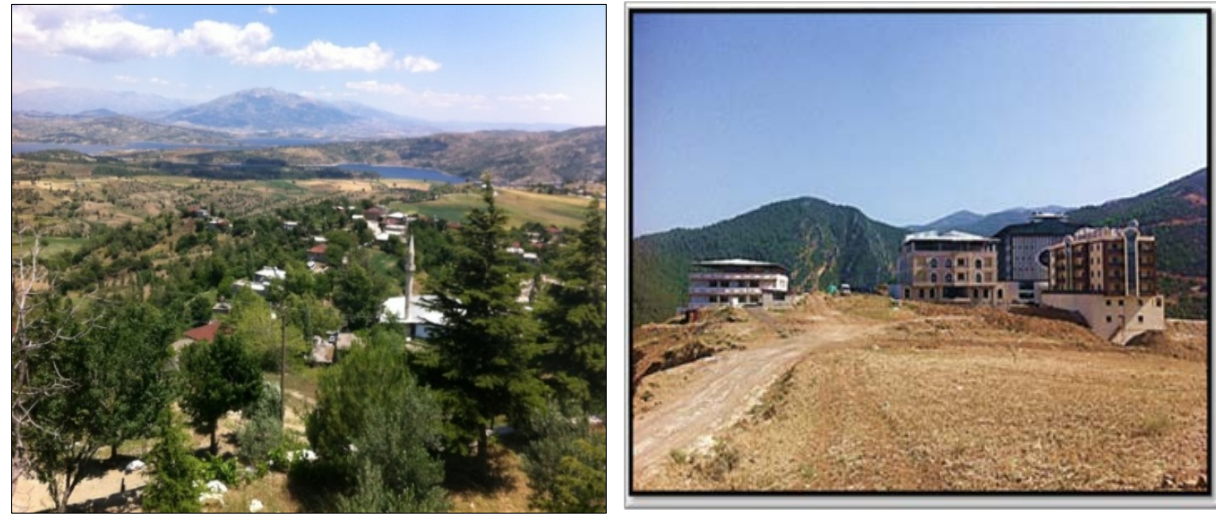

Fotoğraf 1. Döngele yerleşmesi ve oteller bölgesinden görünüş.

Mahallede ön plana çıkan yerleşme özellikleri incelendiğinde, bazı önemli öğelerin varlığı ortaya çıkmaktadır. Döngele Mahallesi sınırları dâhilinde tarihi Gene Köprüsü bulunmaktadır. Bu köprü, Kültür Bakanlığı tarafindan 1986 yıl ve 2876 sayılı kararla tescil edilmiş, fakat daha sonra Sır Barajı gölünün altında kalmıştır (Özkarcı, 2007). Bunun yanı sıra yerleşmede Göğbek ziyaret yerinin de bulunduğu bilinmektedir. Burası Döngele'ye $3 \mathrm{~km}$ mesafede Geneağz1 mevkiinde olup, eski irmak yatağında köprüye yaklaşık $500 \mathrm{~m}$ mesafede bulunmaktadır. Burada bir çevlik (suyun ters akıntılarla birleşerek dönmesi neticesinde oluşan çukurluk, anafor) bulunmaktadır. Bu çevlik yöre halkı 
tarafından kutsal kabul edilmektedir. Ayrıca Göğbek ziyaret yeri birçok hastalık için şifa bulmak amaciyla gelinen bir yerdir (Karaoğlan, 2014).

Sır Barajı, Kahramanmaraş'ın merkez ilçesinde, Ceyhan Nehri üzerinde enerji üretmek amacıyla 1987-1991 yılları arasında inşa edilmiştir. Kamuya ait olan Elektrik Üretim A.Ş. (EÜAŞ) tarafından işletilen bu santral, 283,50 MWe kurulu gücü ile Türkiye'nin 61. Kahramanmaraş'ın ise 3. büyük enerji santralidir. Bunun yanı sıra tesis Türkiye'nin 17. büyük Hidroelektrik Santrali'dir. Sir Barajı ve HES ortalama 648.166.133 kilowatt saat elektrik üretimi sağlamaktadır. Sır Baraj1 ve HES'in, konut elektrik tüketimi dikkate alındığında 205.767 konutun elektrik enerjisi ihtiyacını karşılayabilecek elektrik üretimi yapmaktadır (www.enerjiatlasi.com). Kahramanmaraş'ın $8 \mathrm{~km}$. batısından başlayan Sır Barajı'nın 38 km'lik bir (doğu-batı) uzantısı bulunmaktadır. Ayrıca, girintili ve çıkıntılı bir görünüm arz etmesinden dolayı, baraj kıyıları az engebeli ve düzlük alanlardan meydana geldiği için piknik yapmaya ve dinlenmeye müsait bir alandır. Ayrıca göz alıcı manzarası ile Döngele yerleşmesinin bulunduğu alana ayrı bir değer katmaktadır. Baraj sahasında bol miktarda balık avlanmaktadır ve barajın üst kısmında yer alan Ceyhan Köprüsü civarlarında sıklıkla rekreatif faaliyetler yapılmaktadır (Fotoğraf 2).

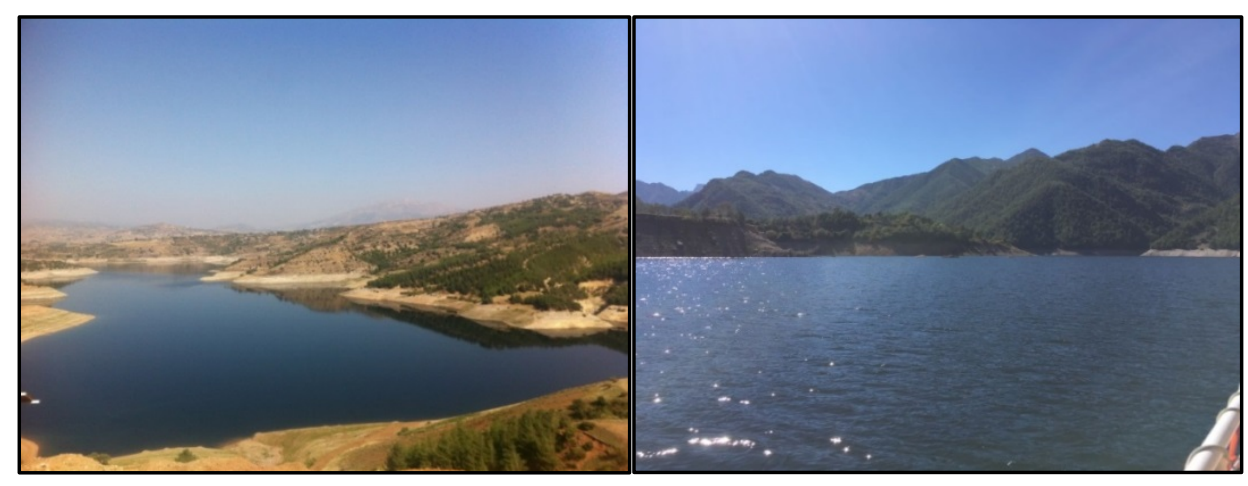

Fotoğraf 2. Sir Barajından görünüm.

\section{Anketlerin Değerlendirilmesi}

Çalışmanın bu bölümünde, Döngele Mahallesinde yaşayan halka ve yöreye gelen ziyaretçilere yapılan anket sonuçları değerlendirilmiştir.

Döngele'de yaşayan halkın kaplıca ile ilgili düşüncelerini yansıtan anket bulgularına göre katılımcıların \%57,4'ünü erkekler oluştururken, \%42,6'sını kadınlar oluşturmuştur. Bunlardan \%84,5'i evli, \%15,5' $\mathrm{i}$ ise bekârdır. Katılımcıların yaş durumları incelendiğinde, \%40,3 oranı ile en fazla 36-50 arasındaki yaş grubu araştırmaya katıldığı gözlemlenmektedir. 19-35 yaş grubu 
katılımcılar ise $\% 23,3$ oranı ile araştırmaya en az katılan yaş grubudur. Araştırmaya katılanların, \%46's1 "ilkokul ve ortaokul" mezunudur. Ayrica $\% 16,3$ 'ü "okuryazar değilken”, \%8,5'i “üniversite" mezunlarıdır. Katılımcıların büyük oranda ortaokul ve lise mezunu olduğu, üniversite okuyanların oldukça az olduğu ve okuryazar olmayanların dahi yörede bulunduğu gözlemlenmiştir. Yörede yaşayanların \%30,2'si "serbest meslek" yaparken, özellikle de kadın katılımcıların büyük bir kısmının "ev hanımı" olduğu dikkat çekmektedir. Katılımcıların \%46'sı memur, işçi, öğrenci ve emekli olanlardır. Döngele Mahallesinde en az yapılan meslek "çiftçiliktir". Bunun temel nedeni ise Kahramanmaraş'ın merkez ilçesi olan Onikişubat'a bağlı bir mahalle statüsünde olması ve insanların şehir merkezinde çalışıp, yöreye günlük gidiş geliş yapmalarıdır (Tablo 4).

Tablo 4. Katılımcıların cinsiyet, yaş, eğitim, meslek ve medeni durumu.

\begin{tabular}{|l|l|l|l|l|l|}
\hline Cinsiyet & $\mathbf{n}$ & $\mathbf{\%}$ & Yaş & $\mathbf{n}$ & $\mathbf{\%}$ \\
\hline Erkek & 74 & 57,4 & $19-35$ & 30 & 23,3 \\
\hline Kadın & 55 & 42,6 & $36-50$ & 52 & 40,3 \\
\hline Toplam & $\mathbf{1 2 9}$ & $\mathbf{1 0 0}$ & $51-64$ & 35 & 27,1 \\
\hline Medeni Durum & $\mathbf{n}$ & $\mathbf{\%}$ & $65+$ & 12 & 9,3 \\
\hline Evli & 109 & 84,5 & Toplam & $\mathbf{1 2 9}$ & $\mathbf{1 0 0}$ \\
\hline Bekâr & 20 & 15,5 & Meslek & $\mathbf{n}$ & $\mathbf{0}$ \\
\hline Toplam & $\mathbf{1 2 9}$ & $\mathbf{1 0 0}$ & Serbest Meslek & 39 & 30,2 \\
\hline Ĕgitim Durumu & $\mathbf{n}$ & $\mathbf{9}$ & Ev hanımı & 27 & 20,9 \\
\hline Okuryazar Değil & 21 & 16,3 & Memur & 25 & 19,4 \\
\hline İlkokul & 38 & 29,5 & İşi & 14 & 10,9 \\
\hline Ortaokul & 25 & 19,4 & Öğrenci & 12 & 9,3 \\
\hline Lise & 34 & 26,4 & Emekli & 10 & 7,8 \\
\hline Üniversite & 11 & 8,5 & Çiftçi & 2 & 1,6 \\
\hline Toplam & $\mathbf{1 2 9}$ & $\mathbf{1 0 0}$ & Toplam & $\mathbf{1 2 9}$ & $\mathbf{1 0 0}$ \\
\hline
\end{tabular}

Döngele'de yaşamakta olan katılımcılar, yörede turizm açısından değer taşıyan özelliklerin sırasıyla kaplıca, yaylalar, doğal güzellikler ile konaklama ve eğlence merkezleri olduğunu ifade etmişlerdir. Özellikle de katılımcıların \%34,9'u kaplıcaların yöreye turizm açısından değer kattığını söylemesi, yörenin en önemli turizm değerlerinden birinin termal turizm olduğunu göstermektedir. Yöre turizminin olumlu etkilerine ise katılımcıların \%42,6's1 "gelir düzeyi artışı", $\% 40,3$ 'ü ise "yeni iş olanakları sağlaması" olarak ifade etmiştir. Geriye kalanlar ise "tanıtıma olumlu bir etkisinin" olduğunu ve "yöre halkının kültür düzeyinde artışa"” sebep olduğunu söylemişlerdir. Ayrıca katılımcılara sürdürülmekte olan turizm faaliyetlerinin sosyal çevre üzerindeki etkisi sorulduğunda, \%73,6's1 
"olumlu etkilemekte" olduğunu, \%24'ü "herhangi bir etkisinin olmadığını" ifade ederken, yalnızca \%2,3'ü "olumsuz etkilemekte" olduğunu cevap olarak vermiştir. $\mathrm{Bu}$ durum açıkça göstermektedir ki termal turizm yöre halkını “olumlu” yönde etkilemiştir (Tablo 5).

Tablo 5. Yörenin turizm çekicilikleri, yöre turizminin olumlu etkileri ve sürdürülen turizm faaliyetlerinin sosyal çevre üzerindeki etkisi.

\begin{tabular}{|l|l|l|}
\hline Yörenin Turizm Değeri & $\mathbf{n}$ & $\mathbf{\%}$ \\
\hline Kaplıcaları & 45 & 34,9 \\
\hline Yaylaları & 36 & 27,9 \\
\hline Doğal Güzellikleri & 35 & 27,1 \\
\hline Konaklama ve Eğlence Merkezleri & 13 & 10,1 \\
\hline Toplam & $\mathbf{1 2 9}$ & $\mathbf{1 0 0}$ \\
\hline Yöre Turizminin Olumlu Etkileri & $\mathbf{n}$ & $\mathbf{\%}$ \\
\hline Gelir Düzeyi Artış1 & 55 & 42,6 \\
\hline Yeni İş Olanakları & 52 & 40,3 \\
\hline Tanıtıma olan Olumlu Etkisi & 15 & 11,6 \\
\hline Yöre Halkının Kültür Düzeyinin Artış1 & 7 & 5,4 \\
\hline Toplam & $\mathbf{1 2 9}$ & $\mathbf{1 0 0}$ \\
\hline Sürdürülen Turizm Faaliyetlerinin Sosyal Çevre Üzerindeki & $\mathbf{n}$ & $\mathbf{2}$ \\
\hline Etkisi & 95 & 73,6 \\
\hline Olumlu Etkilemekte & 31 & 24 \\
\hline Etkisi Yoktur & 3 & 2,3 \\
\hline Olumsuz Etkilemekte & $\mathbf{1 2 9}$ & $\mathbf{1 0 0}$ \\
\hline Toplam & & \\
\hline
\end{tabular}

Katılımcıların turizm faaliyetlerindeki geçmişten bugüne gerçekleşen değişimleri, \%49,6'sı gelen "turist sayısındaki artış", \%34,9'u "turistlerin bölgeye daha fazla para bırakması" ve \% 10,1 ' $\mathrm{i}$ "gelen turist değişiklikleri” olarak sıralamışlardır. Çok az bir kısım olan \%5 civarındaki katılımcılar ise turistlerin ilgi gösterdikleri aktivitelerin değiştiğini ve turistlerin geldiği şehirlerin farklılaşmakta olduğunu gözlemlemiştir. Katılımcıların anketlere vermiş oldukları cevaplar dikkate alındığında, son zamanlarda Döngele Kaplıcasına Kahramanmaraş dışından da birçok turist geldiği gözlemlenmiştir (Tablo 6).

Tablo 6. Turizm faaliyetlerinde geçmişten bugüne gerçekleşen değişimler ve yörede turizme alternatif olabilecek alanlar.

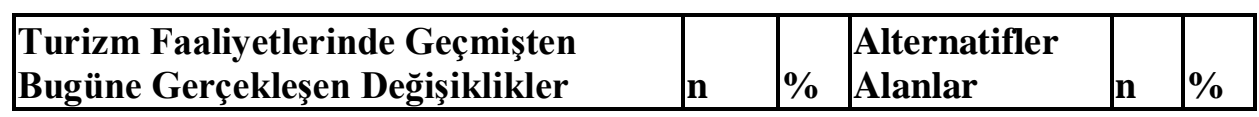




\begin{tabular}{|l|l|l|l|l|l|} 
Gelen Turist Sayısında Artış & 64 & $\begin{array}{l}49, \\
6\end{array}$ & Tarım & 50 & $\begin{array}{l}38, \\
8\end{array}$ \\
\hline $\begin{array}{l}\text { Turistlerin Bölgeye Daha Fazla Para } \\
\text { Bırakması }\end{array}$ & 45 & $\begin{array}{l}34, \\
9\end{array}$ & Hayvancılık & 40 & 31 \\
\hline Gelen Turist Profili Değişmiştir & 13 & $\begin{array}{l}10, \\
1\end{array}$ & Ticaret & 10 & 7,8 \\
\hline Turistlerin İlgi Gösterdikleri Aktiviteler & 4 & 3,1 & Ormancılık & 6 & 4,7 \\
\hline Turistlerin Geldikleri Şehirler & 3 & 2,3 & Diğer & 23 & $\begin{array}{l}17 \\
8\end{array}$ \\
\hline Toplam & $\mathbf{1 2 9}$ & $\mathbf{1 0 0}$ & Toplam & $\mathbf{1 2 9}$ & $\mathbf{1 0 0}$ \\
\hline
\end{tabular}

Yörede turizm faaliyetlerin uygulandığı mevsimlere katılımc1ların \%51,9'u "ilkbahar", \%24'ü "tüm yıl boyunca", \%10,1'i "kış", yine \%10,1'i "yaz" ve \%3,9'u "sonbahar" cevabını vermiştir. Araştırmadaki bu bulgular ise yörede turizm faaliyetlerinin tüm yıl boyunca yapıldığını, fakat özellikle ilkbaharda bu faaliyetler artarken, sonbaharda oldukça az olduğunu ortaya çıkarmaktadır. Katılımcıların \%40,3'ü yöredeki uygun konaklama tesislerinin "büyük oteller "olduğunu söylerken, \%37,2'si "pansiyonların" ve \%22,5'i "apart otellerin" uygun olduğunu ifade etmiştir. Katılımcıların \%24'ü "lokanta ve kafeteryaları", \%19,4'ü "alışveriş alanlarını", \%18,6'sı "otel ve pansiyonları", \%17,1'i "turizm danışma bürolarını", \%9,3'ü "kamp ve karavan alanlarını", yine \%9,3'ü "turizm işaret ve levhalarını" ve \%2,3'ü "hediyelik eşya satan yerleri” yöredeki turistik tesis ve hizmetler açısından yetersiz bulmaktadır (Tablo 7).

Tablo 7. Yörede turizm faaliyetlerinin uygulandığı mevsimler, turizm için uygun konaklama tesisleri ve yetersiz görülen turistik tesis ve hizmetler.

\begin{tabular}{|l|l|l|}
\hline Turizm Faaliyetlerinin Uygulandı̆̆ı Mevsimler & n & $\mathbf{\%}$ \\
\hline İlkbahar & 67 & 51,9 \\
\hline Sonbahar & 5 & 3,9 \\
\hline Kış & 13 & 10,1 \\
\hline Yaz & 13 & 10,1 \\
\hline Tüm Y1l Boyunca & 31 & 24 \\
\hline Toplam & $\mathbf{1 2 9}$ & $\mathbf{1 0 0}$ \\
\hline Turizm İçin Uygun Konaklama Tesisleri & $\mathbf{n}$ & $\mathbf{\%}$ \\
\hline Büyük Oteller & 52 & 40,3 \\
\hline Pansiyonlar & 48 & 37,2 \\
\hline Apart Oteller & 29 & 22,5 \\
\hline Toplam & $\mathbf{1 2 9}$ & $\mathbf{1 0 0}$ \\
\hline Yetersiz Görülen Turistik Tesis ve Hizmetler & $\mathbf{n}$ & $\mathbf{\%}$ \\
\hline Lokanta ve Kafeteryalar & 31 & 24 \\
\hline
\end{tabular}




\begin{tabular}{|l|l|l|}
\hline Kamp veya Karavan Alanları & 12 & 9,3 \\
\hline Otel ve Pansiyonlar & 24 & 18,6 \\
\hline Alışveriş Alanları & 25 & 19,4 \\
\hline Turizm Danışma Büroları & 22 & 17,1 \\
\hline Turizm İşaret ve Levhalar & 12 & 9,3 \\
\hline Hediyelik Eşya Satan Yerler & 3 & 2,3 \\
\hline Toplam & $\mathbf{1 2 9}$ & $\mathbf{1 0 0}$ \\
\hline
\end{tabular}

Yörede gerçekleştirilen turizm faaliyetlerinde çevreye duyarlılık konusunda katılımc1ların \%55'i "kesinlikle duyarlı", \%31,8'i "k1smen duyarlı" ve \%13,2'si "duyarsız" olduğunu belirtmişlerdir. $\mathrm{Bu}$ durum büyük oranda çevreye duyarlılığın olduğunu fakat yine de çevreye duyarlılık konusunda daha da fazla tedbir alınması gerektiğini göstermektedir. Yörede yaşayan katılımcılar turizm etkilerinden \%66,7'si “ekonomik kazanç sağladığ için memnun", \%31,8'i “farklı kültürleri tanıttığı için memnun" olurken \%1,6's1 yani çok az bir kısmı "hayat pahalılığına sahip" olduğu için "memnun değildir". Genel itibari ile halkın turizmin etkilerinden ekonomik ve sosyal yönden memnun olduğu görülmektedir. Yine çalışmada halkın doğal çevrenin korunmasındaki duyarlılığına \%48,1'i "tamamen duyarlı" olunduğu, \%36,4'ü "kısmen duyarlı" olduğunu ve 15,5 'i ise "duyarsız" olunduğunu ifade etmiştir. $\mathrm{Bu}$ ise yörede yaşayan halkın çevreye duyarlılık konusunda bilinçlendirilmesinin gerekliliğini ortaya çıkarmaktadır (Tablo 8).

Tablo 8. Yörede gerçekleştirilen turizm faaliyetlerinin çevreye duyarlılığı, halkın doğal çevrenin korunmasına duyarlılığ 1 ve turizmin etkilerinden memnuniyet durumu ve nedenleri.

\begin{tabular}{|l|c|c|l|l|l|l|l|l|}
\hline $\begin{array}{l}\text { Turizm } \\
\text { Faaliyetleri } \\
\text { nde Çevreye } \\
\text { Duyarlılık }\end{array}$ & $\mathbf{n}$ & \% & $\begin{array}{l}\text { Halkın } \\
\text { Doğal } \\
\text { Cevrenin } \\
\text { Korunmas } \\
\text { Ina } \\
\text { Duyarlı.ı̆ı }\end{array}$ & $\mathbf{n}$ & $\mathbf{\%}$ & $\begin{array}{l}\text { Turizm } \\
\text { Etkilerin } \\
\text { den } \\
\text { Memnun } \\
\text { Olma } \\
\text { Durumu }\end{array}$ & $\mathbf{n}$ & $\mathbf{\%}$ \\
\hline $\begin{array}{l}\text { Kesinlikle } \\
\text { Duyarlı }\end{array}$ & 71 & 55 & $\begin{array}{l}\text { Tamamen } \\
\text { Duyarlı }\end{array}$ & 62 & 48,1 & $\begin{array}{l}\text { Ekonomik } \\
\text { Kazanç } \\
\text { Sağladığı } \\
\text { çin } \\
\text { Memnunu } \\
\text { m }\end{array}$ & 86 & 66,7 \\
\hline
\end{tabular}




\begin{tabular}{|c|c|c|c|c|c|c|c|c|}
\hline $\begin{array}{l}\text { Kismen } \\
\text { Duyarl1 }\end{array}$ & 41 & 31,8 & $\begin{array}{l}\text { Kismen } \\
\text { Duyarlı }\end{array}$ & 47 & 36,4 & $\begin{array}{l}\text { Farklı } \\
\text { Kültürleri } \\
\text { Tanıttığı } \\
\text { için } \\
\text { Memnunu } \\
\text { m }\end{array}$ & 41 & 31,8 \\
\hline Duyarsiz & 17 & 13,2 & Duyarsiz & 20 & 15,5 & $\begin{array}{l}\text { Hayat } \\
\text { Pahalılığın } \\
\text { a sebep } \\
\text { olduğu } \\
\text { için } \\
\text { Memnun } \\
\text { Değilim }\end{array}$ & 2 & 1,6 \\
\hline Toplam & 129 & \begin{tabular}{|l|}
100 \\
\end{tabular} & Toplam & 129 & 100 & Toplam & 129 & 100 \\
\hline
\end{tabular}

Katılımcılar, yöre halkının da turizme katılması ve gelir elde etmesi için yapılması gerekenlere $\% 45$ ' i "merkezi ve yerel yönetimlerin halkı turizme teşvik etmesi”" gerektiğini ifade etmişlerdir. Diğerlerinin \%26,4'ü “sürdürülebilir turizm ve kalkınma konusunda eğitim ve bilinç kazandırılmasını", \%14'ü “yöre halkının da turizm faaliyetlerine katılımının sağlanmasını", \%9,3'ü "turistik çekiciliklerin arttırılması ve korunmasını" söylerken, \%5,4'ü ise" kalkınma ajanslarının turizm projelerinin geliştirmesinde destek olması" gerektiğini belirtmiştir (Tablo 9).

Tablo 9. Yöre halkının da turizme katılması ve gelir elde etmek için yapılması gerekenler.

\begin{tabular}{|l|l|l|}
\hline $\begin{array}{l}\text { Yöre Halkının da Turizme Katılması ve Gelir Elde Etmek } \\
\text { için Yapılması Gerekenler }\end{array}$ & $\mathbf{n}$ & $\mathbf{\%}$ \\
\hline Merkezi ve Yerel Yönetimlerin Halkı Turizme Teşvik Etmesi & 58 & 45 \\
\hline $\begin{array}{l}\text { Sürdürülebilir Turizm ve Kalkınma Konusunda Eğitim ve Bilinç } \\
\text { kazandırılmalı }\end{array}$ & 34 & 26,4 \\
\hline Yöre Halkının da Turizm Faaliyetlerine Katılımı Sağlanmalı & 18 & 14 \\
\hline Turistik Çekiciliklerin Arttırılması ve Korunması & 12 & 9,3 \\
\hline $\begin{array}{l}\text { Kalkınma Ajanslarının Turizm Projelerinin Geliştirmesinde } \\
\text { Destek Olması }\end{array}$ & 7 & 5,4 \\
\hline Toplam & $\mathbf{1 2 9}$ & $\mathbf{1 0 0}$ \\
\hline
\end{tabular}

Çalışmada Döngele Kaplıcasına turizm amaçlı olarak gelen ziyaretçilerin anket sonuçları da değerlendirilmiştir. 
Elde edilen bulgulara göre katılımcıların, \%59,9'ü erkek ve \%40,1'i kadınlardan oluşmaktadır. Katılımcıların \%59'dan fazlasının erkek olması, erkeklerin aileleri olmasa dahi hemcinsleri ile dinlenme ve eğlenme amaçlı olarak kısa süreli de olsa Kahramanmaraş ve çevresinde gezme kültüründen kaynaklandığ 1 düşünülmektedir. Araştırmada yer alan katılımcıların, \%26,5'i "21-35" yaş grubunda yer alanlar, \%34'ü "36-50" yaş grubunda yer alanlar, $\% 29,9$ 'u " $51-64$ " yaş grubundakiler ve $\% 9,5$ ' $\mathrm{i}$ " 65 yaş ve üzeri” yaş grubundan oluşmaktadır. Katılımcıların \%71,4'ü “evli” ve \%28,6’sı "bekârdır” (Tablo 10). 51 yaşının üzerinde kaplıcaya gelenlerin oranı ise \%39 civarındadır. $\mathrm{Bu}$ sonuçlardan yola çıkarak Döngele'ye termal turizm için gelen insanların büyük bir çoğunluğunu 36 yaşın üzerindekilerin oluşturduğunu söyleyebiliriz. Ayrıca 19-35 yaş arasındaki kaplıcaya gelen \%23 civarındakilerin de bir kısmının yöreye ailesi ile birlikte geldiği tespit edilmiştir.

Kat1lımc1ların, \%17'si “ilkokul”, \%12,2's1 "ortaokul ”, \% 34'ü "lise”, \% 36,7'si ise "üniversite mezunudur". Yine kat1lımc1ların \%32,7'si "memur", \%31,3'ü "serbest meslek", \%13,6's1 "ev hanımı", \%8,8'i "işçi”, \%8,2'si "emekli," \%3,4'ü "öğrenci” ve \%2'si "öğretmen"dir. Ayrıca katılımcıların \%34,7'si “1500-2500” lira ve alt1, \%17,7'si “2501-3500” lira aras1, \%37,4'ü "3500-5000" lira aras1 ve \%10,2'si" 5001" lira ve üzeri gelir düzeyine sahiptir (Tablo 10). Bu oranlara göre 2501-3500 lira arasında gelire sahip olan insanların kaplıcayı daha fazla tercih ettiği gözlemlenmiştir. Ayrıca burayı daha çok memur ve serbest meslek ile uğraşan kişiler tercih etmiştir. Kaplıcaya gelenlerin \%70'den fazlasının lise ve üniversite mezunu olması, eğitim seviyesi açısından yüksek olan insanların bu tesisleri tercih ettiğini göstermektedir. Kaplıcaya gelen ziyaretçiler arasındaki katılımcıların $\% 56,5$ 'i "dost, arkadaş ya da akraba tavsiyesi” ile gelmiştir. Diğerleri ise \%16,3'ü "internet sitesi”, \%8,8'i” katalog veya broşürlerden", \%8,2'si "doktor tavsiyesiyle," \%6,8'i "seyahat acentesi" ile yöreye gelirken, \%3,4’ü "daha önceki tecrübeleri ile" gelmiştir (Tablo 10).

Tablo 10. Katılımcıların cinsiyet, yaş, eğitim, meslek, aylık gelir durumu, medeni durumu ve kaplıcaya kimin tavsiyesi ile geldiği.

\begin{tabular}{|l|l|l|l|l|l|}
\hline Cinsiyet & n & $\mathbf{\%}$ & Medeni Durum & $\mathbf{n}$ & $\mathbf{\%}$ \\
\hline Erkek & 88 & 59,9 & Evli & 105 & 71,4 \\
\hline Kadın & 59 & 40,1 & Bekâr & 42 & 28,6 \\
\hline Toplam & $\mathbf{1 4 7}$ & $\mathbf{1 0 0}$ & Toplam & $\mathbf{1 4 7}$ & $\mathbf{1 0 0}$ \\
\hline Yaş & $\mathbf{n}$ & $\mathbf{\%}$ & Meslek & n & $\%$ \\
\hline $21-35$ & 39 & 26,5 & Memur & 48 & 32,7 \\
\hline $36-50$ & 50 & 34 & Serbest meslek & 46 & 31,3 \\
\hline $51-64$ & 44 & 29,9 & Ev hanım1 & 20 & 13,6 \\
\hline $65+$ & 14 & 9,5 & İşi & 13 & 8,8 \\
\hline
\end{tabular}




\begin{tabular}{|l|l|l|l|l|l|} 
Toplam & $\mathbf{1 4 7}$ & $\mathbf{1 0 0}$ & Emekli & 12 & 8,2 \\
\hline Ĕgitim Durumu & $\mathbf{n}$ & $\mathbf{\%}$ & Öğrenci & 5 & 3,4 \\
\hline İlkokul & 25 & 17 & Öğretmen & 3 & 2 \\
\hline Ortaokul & 18 & 12,2 & Toplam & $\mathbf{1 4 7}$ & $\mathbf{1 0 0}$ \\
\hline Lise & 50 & 34 & $\begin{array}{l}\text { Kimin Tavsiyesi ile } \\
\text { Geldiği }\end{array}$ & $\mathbf{n}$ & $\mathbf{\%}$ \\
\hline Üniversite & 54 & 36,7 & $\begin{array}{l}\text { Dost, Arkadaş ya da } \\
\text { Akraba }\end{array}$ & 83 & 56,5 \\
\hline Toplam & $\mathbf{1 4 7}$ & $\mathbf{1 0 0}$ & İnternet Sitesi & 24 & 16,3 \\
\hline $\begin{array}{l}\text { Aylı Gelir } \\
\text { Durumu }\end{array}$ & $\mathbf{n}$ & $\mathbf{\%}$ & Katalog/Broşür & 13 & 8,8 \\
\hline 1500-2500 & 51 & 34,7 & Doktor Tavsiyesi & 12 & 8,2 \\
\hline $2501-3500$ & 26 & 17,7 & Seyahat Acentesi & 10 & 6,8 \\
\hline 3500-5000 & 55 & 37,4 & Daha Önceki Tecrübe & 5 & 3,4 \\
\hline $5001+$ & 15 & 10,2 & Toplam & $\mathbf{1 4 7}$ & $\mathbf{1 0 0}$ \\
\hline Toplam & $\mathbf{1 4 7}$ & $\mathbf{1 0 0}$ & & & \\
\hline
\end{tabular}

Araştırmaya katılanların \%37,4'ü "romatizmal hastalıklar", \%12,2'si "kas yorgunlukları", \%9,5'i “damar sertliği”, \%5,4'ü “cilt hastalıkları”, \%4,8’i "böbrek, idrar yolları ve safra kesesi taşları", \%4,8'i "mide ve bağırsak tembellikleri "ve \%3,4'ü "idrar yolları iltihabı "hastalıkları ile Döngele Kaplıcasına gelmiştir. Ayrıca katılımcılardan \%22,4'ü "herhangi bir hastalık amaçlı olarak gelmediklerini”" belirtmiştir. Bu sonuçlar da göstermektedir ki kaplıcaya gelen ziyaretçilerin \%77'si bir hastalığın tedavisi için gelmektedir. Özellikle de bu hastalıkların başında romatizmal hastalıklar ve kas yorgunlukları gelmektedir. Hastalık tedavisi için yöreye gelen ziyaretçilerden araştırmaya katılanların \%37,4'ü "tıbbi tedavi ile birlikte olması gerektiğini”, \%36,1'i "alternatif bir tedavi yöntemi" olduğunu ve $\% 26,5$ 'i "farklı bir tedavi şekli" olduğunu ifade etmişlerdir. Katılımcıların \%46,9'u "yöreyi termal suyun özelliğinden" dolayı, \%27,2'si "kaplıcanın yakınlığından", \%18,4'ü “iklim uygunluğundan" ve \%7,5'i "ücret uygunluğundan" dolayı seçmiştir. Katılımcıların kaplıcada kalma süreleri incelendiğinde, \%36,7 "hafta sonu", \%27,9 "bir gün”, \%30,6 “3-7 gün” ve \%4,8 "8-14” gün süre ile kaldığ 1 gözlemlenmiştir. Bu konaklamalarda ise katılımcıların \%83,7'si kalış yeri olarak otelleri tercih ederken, \%16,3'ü pansiyonları tercih etmektedir (Tablo 11).

Araştırmaya katılanların \%36,1'i “eşiyle”, \%27,9'u “ailesiyle", \%23,1'i "arkadaşıyla" ve \%12,9'u "yalnız" geldiğini ifade etmiştir. Katılımcılara Döngele Kaplicaların tavsiye edip etmedikleri sorulduğunda, \%68'i "tavsiye etmekte", $\% 9,5$ 'i "tavsiye etmemekte" iken, \%22,4'ü "kısmen tavsiye ettiğini” belirtmiştir. Katılımcıların konaklamış oldukları tesislerden memnuniyet durumlarına 
bakıldığında, \%69,4'ü “memnun”, \%10,2'si “memnun olmamış” ve \%20,4'ü "kısmen memnun" kalmıştır. Yörenin doğal güzelliklerinden memnun olma durumuna ise kat1lımc1ların \%86,4'ü “iyi”, \%4,1'i "kötü” ve \%9,5'i “idare eder" cevabını vermiştir (Tablo 11). Bu sonuçlarda göstermektedir ki Döngele’yi tercih eden turistlerin büyük çoğunluğu hem tesislerden hem de yörenin doğal güzelliklerinden memnun kalmaktadır. Çok az bir kısım memnun kalmazken bazıları kısmen cevabını vermiştir. Bu durum da bu termal tesislerin eksik olan yönlerinin geliştirilmesi durumunda daha da iyi bir turistik mekân haline geleceğini göstermektedir.

Tablo 11. Katılımcıların Döngele Kaplıcasına tedavisini görmek için geldikleri hastalıklar, seçme nedenleri, kalma süresi, konaklama tesis türü, kimle geldiği, tedavilerin değerlendirilmesi, tavsiye durumu, tesislerden memnuniyet ve tatminkârlık durumları.

\begin{tabular}{|c|c|c|c|c|c|}
\hline $\begin{array}{l}\text { Tedavisi için Gelinen } \\
\text { Hastalıklar } \\
\end{array}$ & $\mathbf{n}$ & $\%$ & Kiminle Geldiniz & $\mathbf{n}$ & $\%$ \\
\hline Romatizmal Hastalıklar & 55 & 37,4 & Eşimle & 53 & 36,1 \\
\hline Hastalık Amaçlı Değil & 33 & 22,4 & Ailemle & 41 & 27,9 \\
\hline Kas yorgunlukları & 18 & 12,2 & Arkadaşımla & 34 & 23,1 \\
\hline Damar Sertliği & 14 & 9,5 & Yalnız & 19 & 12,9 \\
\hline Cilt Hastalıkları & 8 & 5,4 & Toplam & 147 & 100 \\
\hline $\begin{array}{l}\text { Böbrek, İdrar Yolları ve Safra } \\
\text { Kesesi Taşları }\end{array}$ & 7 & 4,8 & $\begin{array}{l}\text { Tedavilerin } \\
\text { Değerlendirilmesi }\end{array}$ & n & $\%$ \\
\hline Mide ve Bağırsak Tembellikleri & 7 & 4,8 & $\begin{array}{l}\text { Tibbi Tedavi ile } \\
\text { Birlikte Olmalı }\end{array}$ & 55 & 37,4 \\
\hline İdrar Yolları İltihapları & 5 & 3,4 & Alternatif & 53 & 36,1 \\
\hline Toplam & 147 & 100 & Farklı bir Tedavi & 39 & 26,5 \\
\hline Seçme Nedenleri & $\mathbf{n}$ & $\%$ & Toplam & 147 & 100 \\
\hline Termal Suyun Özelliği & 69 & 46,9 & Tavsiye Durumu & $\mathbf{n}$ & $\%$ \\
\hline Yakınlık & 40 & 27,2 & Evet & 100 & 68 \\
\hline İklim Uygunluğu & 27 & 18,4 & Hayır & 14 & 9,5 \\
\hline Ücret Uygunluğu & 11 & 7,5 & Kismen & 33 & 22,4 \\
\hline Toplam & 147 & 100 & Toplam & 147 & 100 \\
\hline Kalma Süresi & $\mathbf{n}$ & $\%$ & \begin{tabular}{|l|} 
Tesislerden \\
Memnuniyet
\end{tabular} & $\mathbf{n}$ & $\%$ \\
\hline Hafta Sonu & 54 & 36,7 & Evet & 102 & 69,4 \\
\hline 1 Gün & 41 & 27,9 & Hayır & 15 & 10,2 \\
\hline 3-7 Gün & 45 & 30,6 & Kismen & 30 & 20,4 \\
\hline 8-14 Gün & 7 & 4,8 & Toplam & 147 & 100 \\
\hline
\end{tabular}




\begin{tabular}{|l|l|l|l|l|l|} 
Toplam & $\mathbf{1 4 7}$ & $\mathbf{1 0 0}$ & $\begin{array}{l}\text { Yörenin doğal } \\
\text { güzellerinden } \\
\text { memnuniyet }\end{array}$ & $\mathbf{n}$ & $\mathbf{\%}$ \\
\hline Konaklama Tesis Türü & $\mathbf{n}$ & $\mathbf{\%}$ & İyi & 127 & 86,4 \\
\hline Otel & 123 & 83,7 & Kötü & 6 & 4,1 \\
\hline Pansiyon & 24 & 16,3 & İdare Eder & 14 & 9,5 \\
\hline Toplam & $\mathbf{1 4 7}$ & $\mathbf{1 0 0}$ & Toplam & $\mathbf{1 4 7}$ & $\mathbf{1 0 0}$ \\
\hline
\end{tabular}

Araştırmaya katılanların \%34,7'si tesislerdeki boş zamanlarını “dinlenme ve uyuma ile geçirirken, \%21,1’i "kitap veya dergi okuyarak”, \%19,7'si "spor ve yürüyüş yaparak", $\% 15$ 'i "yöresel ürünlerden alışveriş yaparak" ve $\% 9,5$ 'i "gezilere katılarak" değerlendirmektedirler. Döngele'ye gelirken katılımcıların \%66,7'si "özel araç”, \%18,4'ü “otobüs", \%15'i ise "tur” ile ulaşımlarını sağlamışlardır (Tablo 12). Döngele Kaplıcasına ulaşımda herkese hizmet veren ve daha sık aralıklar ile gidiş-geliş yapan modern araçların kullanılması, özel araçları olmayan ve maddi imkânları kısıtlı olan insanların da bu termal turizm faaliyetlerinden faydalanması için oldukça önemlidir. Bu durum yöredeki ticari canlılığı da olumlu yönde etkileyecektir. Ayrıca kaplıcaya tur aracılığı ile gelenlerin bulunması da oldukça önemlidir. Yine daha iyi bir tanıtımla bu turların attırılması turizm üzerinde olumlu bir etki gösterecektir.

Yörede ulaşım sorununun olup olmadığ 1 katılımcılara sorulduğunda $\% 23,8$ 'i "evet", \%53,7'si "hayır" ve \%22,4'ü "kısmen" cevabını vermiştir. Katılımcıların yaklaşık \%75'i yani önemli bir kısmı "ulaşım sorununun olmadığını" ifade etmiştir. Altyapı yeterliliğinde ise katılımcıların \%46,3'ü "altyapının yeterli olduğunu”, \%29,9'u "yeterli olmadığını" ve \%23,8'i "kısmen yeterli” olduğunu ifade etmiştir. Araştırmaya katılanların toplam \%70'i yörede alt yapı sorununun olmadığını belirtmiştir (Tablo 12). Bu sonuçlarda göstermektedir ki belediye ile diğer kurum ve kuruluşlar yörenin gelişimine önem vermektedir. Kaplıcadaki termal turizm potansiyeli de göz önüne alınarak, ulaşım ve altyapı sorunlarını en aza indirmeye gayret gösterildiği gözlemlenmektedir.

Döngele Kaplıcasının yakın ve uzak bölgelerden tanıtım durumunun değerlendirilmesinde katılımcıların \%34'ü "evet”, \%34,7'si "hayır" ve \%31,3'ü" kısmen" cevaplarını vermişlerdir. Bu durumda aslında kaplıca tanıtımının oldukça yetersiz olduğunu göstermektedir. Tekrar gelme durumlarına ise katılımc1ların \%70,1'i “evet", \%4,8'i "hayır" ve \%25,2'si "belki” cevaplarını vermişlerdir (Tablo 12). 
Tablo 12. Katılımcıların, Döngele'de boş zamanı değerlendirme, kaplıcalarındaki turizm altyapısı yeterliliğini değerlendirmesi, ulaşım şekli, ulaşım sorunu, tesislerin tanıtımının yeterliliği ve tekrar gelme durumu.

\begin{tabular}{|c|c|c|c|c|c|}
\hline \begin{tabular}{|l} 
Boş Zamanı \\
Değerlendirme
\end{tabular} & n & $\%$ & Altyapı Yeterliliği & n & $\%$ \\
\hline Dinlenme ve Uyuma & 51 & 34,7 & Evet & 68 & 46,3 \\
\hline Kitap/Dergi Okuma & 31 & 21,1 & Hayır & 44 & 29,9 \\
\hline Spor ve Yürüyüş Yapma & 29 & 19,7 & Kismen & 35 & 23,8 \\
\hline \begin{tabular}{|l|} 
Yöresel Ürünlerden \\
Alışveriş
\end{tabular} & 22 & 15 & Toplam & 147 & 100 \\
\hline Gezilere Katılma & 14 & 9,5 & $\begin{array}{l}\text { Tanıtım Durumu } \\
\text { Yeterliliği }\end{array}$ & n & $\%$ \\
\hline Toplam & 147 & 100 & Evet & 50 & 34 \\
\hline Ulaşım Şekli & n & $\%$ & Hayır & 51 & 34,7 \\
\hline Özel araç & 98 & 66,7 & Kismen & 46 & 31,3 \\
\hline Otobüs & 27 & 18,4 & Toplam & 147 & 100 \\
\hline Tur & 22 & 15 & $\begin{array}{l}\text { Tekrar Gelme } \\
\text { Durumu }\end{array}$ & n & $\%$ \\
\hline Toplam & 147 & 100 & Evet & 103 & 70,1 \\
\hline Ulaşım Sorunu & n & $\%$ & Hayır & 7 & 4,8 \\
\hline Evet & 35 & 23,8 & Belki & 37 & 25,2 \\
\hline Hayır & 79 & 53,7 & Toplam & 147 & 100 \\
\hline Kismen & 33 & 22,4 & & & \\
\hline Toplam & 147 & 100 & & & \\
\hline
\end{tabular}

Döngele Kaplıcasına gelen katılımcıların, \%31,3'ü "doğal ortam güzelliğini," \%25,9'u "kaplica hizmetini", \%20,4'ü tesiste çalışanların "olumlu" yaklaşımlarını, \%7,5'i halkın "olumlu" yaklaşımını ve \%11,6'sı bütün bu özelliklerin "hepsini "olumlu bulmuşlardır. Tesisin olumsuz özelliklerine ise katılımcıların \%27,2'si "doğal ortamın tahrip edilmesi”, \%19'u "kültürel fark", \%16,3'ü kaplıcadaki "hizmetin yetersizliği", \%9,5'i "halkın turistlere olumsuz yaklaşımı", \%7,5'i tesiste "çalışanların olumsuz yaklaşımları" ve \%20,4'ü "hepsi” cevabını vermiştir (Tablo 13).

Araştırmaya katılan ziyaretçilerin, \%64,6's1 yöreye “1-2 defa", \%30,6's1 “3-4 defa" ve $\% 4,8$ 'i "5 defa ya da daha fazla" yöreye gelmişlerdir. Katılımciların $\% 53,1$ 'i “dinlenmek amaciyla", \%35,4'ü "sağllğa yararlı" olduğundan ve \%11,6's1 rahatsız olan "yakınına refakatçi olmak" amacıyla gelmiştir (Tablo 13). $\mathrm{Bu}$ sonuçlardan yola çıkarak 2010 yılında faaliyete geçmiş olan Döngele Kaplıcasını insanlar çeşitli sebeplerle tercih etmektedir. Yöre özellikle de 
dinlenmek maksadıyla tercih edilen yerler arasındadır. Büyük bir çoğunluğunda kaplıcaya ilk defa geldiği hesaba katılırsa, kaplıcanın gelecek vaat eden bir termal turizm tesisi olduğunu söyleyebiliriz.

Tablo 13. Katılımcıları, kaplıcada olumlu ve olumsuz yönde etkileyen özellikler, kaç defa gelindiği, geliş amacı ve tekrar gelme durumu.

\begin{tabular}{|l|l|l|l|l|l|}
\hline Olumlu Özellikleri & $\mathbf{n}$ & $\mathbf{\%}$ & Olumsuz Özellikleri & $\mathbf{n}$ & $\mathbf{\%}$ \\
\hline $\begin{array}{l}\text { Doğal Ortam } \\
\text { Güzelliği }\end{array}$ & 46 & 31,3 & $\begin{array}{l}\text { Doğal Ortamın Tahrip } \\
\text { Edilmesi }\end{array}$ & 40 & 27,2 \\
\hline Kaplıca Hizmeti & 38 & 25,9 & Kültürel Fark & 28 & 19 \\
\hline $\begin{array}{l}\text { Tesiste Çalışanların } \\
\text { Olumlu Yaklaşımı }\end{array}$ & 30 & 20,4 & $\begin{array}{l}\text { Kaplıcadaki Hizmetin } \\
\text { Yetersizliği }\end{array}$ & 24 & 16,3 \\
\hline Kültürel Zenginlik & 11 & 7,5 & $\begin{array}{l}\text { Halkın Turistlere Olumsuz } \\
\text { Yaklaşımı }\end{array}$ & 14 & 9,5 \\
\hline $\begin{array}{l}\text { Halkın Olumlu } \\
\text { Yaklaşımı }\end{array}$ & 5 & 3,4 & $\begin{array}{l}\text { Tesislerde Çalışanların } \\
\text { Olumsuz Yaklaşımları }\end{array}$ & 11 & 7,5 \\
\hline Hepsi & 17 & 11,6 & Hepsi & 30 & 20,4 \\
\hline Toplam & $\mathbf{1 4 7}$ & $\mathbf{1 0 0}$ & Toplam & $\mathbf{1 4 7}$ & $\mathbf{1 0 0}$ \\
\hline Kaç Defa Gelinmiş & $\mathbf{n}$ & $\mathbf{\%}$ & Geliş Amacı & $\mathbf{n}$ & $\mathbf{\%}$ \\
\hline $\mathbf{1 - 2}$ & 95 & 64,6 & Dinlenmek için & 78 & 53,1 \\
\hline 3-4 & 45 & 30,6 & Sağlığa Yararlı Olduğundan & 52 & 35,4 \\
\hline 5+ & 7 & 4,8 & $\begin{array}{l}\text { Rahatsı Olan Yakına } \\
\text { Refakatçı }\end{array}$ & 17 & 11,6 \\
\hline Toplam & $\mathbf{1 4 7}$ & $\mathbf{1 0 0}$ & Toplam & $\mathbf{1 4 7}$ & $\mathbf{1 0 0}$ \\
\hline
\end{tabular}

Yöredeki otellerde çalışan yöneticilerle yapılan mülakatlarda, yörede iki büyük otel ve apart yer aldığını ve bunun yanı sıra yeni inşaatlarında devam ettiğini belirtmişlerdir. Ziyaretçilerin genellikle Kahramanmaraş, Osmaniye, Şanlıurfa, Hatay, Gaziantep, Adıyaman, Malatya il ve ilçelerinden gelmekte olduğu ifade edilmiştir. Bölge dışından olan insanlar burayı pek tercih etmemektedir. Ayrıca otel yöneticileri, otellerde ve pansiyonlarda yöre halkından çalışan çok insanın bulunduğu ve termal tesislerin yöre halkının istihdamını katkı sağladığını belirtmişlerdir. Son zamanlarda ise yöreye, firma acentelerinin turlar düzenlediklerini ifade etmişlerdir. Bunun yanı sıra otellere sağlık sevki ile gelenlerinde bulunması oldukça dikkat çekicidir. Otel yöneticileri, Döngele Mahallesinin önceki yolunun kötü olduğunu fakat turizm faaliyetlerindeki gelişmelere de bağlı olarak yeni yapılan yolun iyi olduğunu ifade etmişlerdir. Tanitımlar yerel boyutta kaldığı için yetersiz olup, özellikle sosyal medya aracılığı ile (İnstegram, Facebook, Twetter vb.) tüm Türkiye'ye hitap etmelidir. 


\section{SONUÇ VE ÖNERÍLER}

Çalışma sahasını oluşturan Döngele Kaplıcasının rekreasyonel faaliyetler ve termal turizm açısından oldukça önemli bir potansiyele sahip olduğu gözlemlenmiştir. Kahramanmaraş merkez ilçesi olan Onikişubat'a bağlı Döngele Kaplıcası sahip olduğu termal kaynaklar, doğal güzellikler ve yükseltisine bağlı olarak turizm ve rekreasyonel faaliyetleri destekleyebilecek nitelikte bir yerdir. Döngele Kaplıcasındaki turizm faaliyetleri yöre halkını oldukça olumlu yönde etkilemiştir. Özelliklede yöre halkından ankete katılanların \%82'si sürdürülen turizm faaliyetleri ile gelir düzeyinde artış olduğunu ve yeni iş olanakları doğduğunu ifade etmiştir. Ayrıca katılımcılar, yöredeki turizm faaliyetlerinde geçmişten bugüne meydana gelen değişimler sorulduğunda; gelen turist sayısındaki artış, turistlerin bölgeye daha fazla para bırakması ve gelen turist sayısındaki değişiklikler olduğunu ileri sürmüştür.

Çalışmada Döngele yerleşmesinde yaşayan halkla yapılan anketlerde, Mahallede yaşayan insanların büyük bir kısmının eğitim seviyesinin yüksek olmadığı görülmüştür. Ekonomik nedenlerden dolayı istihdam sıkıntısı nedeniyle üniversite öğrencileri dışarıya göç etmiştir. Bu nedenle yörede 40 yaş üzeri insanlar daha fazladır. Döngele'deki halk kaplıca turizminin yeni iş olanakları sağlayacağını ve bununda olumlu etkisi sayesinde gelir düzeyinde artışlar olacağını düşünmektedir. Bunun yanı sıra yıllar bazında yöreye gelen turist sayısının arttığı ifade edilmiştir. Ayrıca burada yaşayan insanlar daha çok tarım $(\% 38,8)$ ve hayvancılıkla $(\% 31)$ uğraştıklarını ifade etmişlerdir. Dolayısıyla turizmin yörede canlanması farklı ekonomik getiriler sağlayabilecektir. Döngele Mahallesinde yaşayan insanlar lokanta ve kafeteryaların (\%24) ve alışveriş alanlarının $(\% 19,4)$ yörede yetersiz olduğunu ifade etmişlerdir. Yöre halk1 $(\% 66,7)$, turistlerin yöreye gelip ekonomik kazanç sağladıklarından dolayı, bu sistemin içinde olmaktan oldukça memnundur.

Yöredeki turizm faaliyetlerinin tüm yıl boyunca yapıldığı, özellikle ilkbaharda bu faaliyetler artarken, sonbaharda oldukça az olduğunu ortaya çıkarmaktadır. Döngele'de yaşayan halk, yöredeki uygun konaklama tesislerinin büyük oranda büyük oteller olduğunu belirtmişlerdir. Bunun yanı sıra katılımcılar, bu termal turizm tesisini, yöredeki turistik tesis ve hizmetler açısından yetersiz bulmaktadır. Yörede gerçekleştirilen turizm faaliyetlerinde çevreye duyarlılık konusunda, büyük oranda çevreye duyarlılığın olduğunu fakat yine de daha fazla tedbir alınması gerektiği ifade edilmiştir. Genel itibari ile halkın turizmin etkilerinden ekonomik ve sosyal yönden memnun olduğu görülmektedir. Çalışmada yöre halkının da turizme katılması ve gelir elde etmesi için merkezi ve yerel yönetimlerin turizmi teşvik etmesi, halka sürdürülebilir turizm ve kalkınma konusunda eğitim ve bilinç kazandırılması, turizm faaliyetlerine daha çok katılımın sağlanması, turistik çekiciliklerin arttırılması ve korunması ve kalkınma 
ajanslarının turizm projelerinin geliştirmesine destek olunması gerektiği ortaya çıkmıştır.

Döngele’ye termal turizm tesislerinden yararlanmak ve çevreyi gezmek için gelen katılımcılara uygulanan anket çalışmasında ise ankete katılanların $\% 75$ ' $\mathrm{i}$, 40 yaşının üzerindedir. $\% 50$ 'den fazlası lise ve üzeri eğitim seviyesinde, $\% 70$ 'e yakını 2.500 TL üzeri bir gelir seviyesine sahip, büyük bir kısmı dost, arkadaş ya da akraba tavsiyesi ile gelmesinin yanı sıra bir kısmı da termal suyun özelliğinden dolayı Döngele Kaplıcasını tercih etmiştir. Kaplıcaya gelen ziyaretçiler genellikle dost, arkadaş ya da akraba tavsiyesi ile gelmekle birlikte, bazıları ise internet sitesi, katalog veya broşürlerden, doktor tavsiyesiyle, seyahat acentesiyle ya da daha önceki tecrübeleri ile gelmişlerdir. Kaplıca genel olarak romatizmal hastalıklar, kas yorgunlukları, damar sertliği, cilt hastalıkları, böbrek, idrar yolları ve safra kesesi taşları, mide ve bağırsak tembellikleri ve idrar yolları iltihabı hastalıkları gibi rahatsılıklar için tercih edilmiştir. Bunun yanı sıra bazı ziyaretçiler herhangi bir hastalıktan dolayı değil de dinlenmek amaçlı olarak tesisi tercih etmiştir. Turistlerin \%80'e yakını hem termal tesislerden hem de yörenin doğal güzelliklerinden memnundur. Yine katılımcılar yörede boş zamanlarını daha çok dinlenerek değerlendirmektedir. \%70'den fazlası yöreye ve tesislere yeniden geleceğini ifade etmiştir. Katılımcılar, yörenin doğal ortam güzelliklerinin olduğunu, fakat bunların tahrip edilme risklerinin bulunduğunu ifade etmişlerdir. Bu durum termal tesislerin eksik olan yönlerinin geliştirilmesi durumunda yörenin daha da iyi bir turistik mekân haline geleceğini göstermektedir.

Döngele Kaplıcasına gelen ziyaretçilerin büyük çoğunluğu özel araçları ile gelmektedir. Yörede, ulaşımda herkese hizmet veren ve daha sık aralıklar ile gidiş-geliş yapan modern araçların kullanılması, özel araçları olmayan ve maddi imkânları kısıtlı olan insanlarından bu termal turizm faaliyetlerinden faydalanması için oldukça önemlidir. Bu durum yöredeki ticari canlılı̆̆ 1 da olumlu yönde etkileyecektir. Ayrıca kaplıcaya tur aracılığı ile gelenlerin bulunması da oldukça önemlidir. Yine daha iyi bir tanıtımla bu turların attırılması turizm üzerinde olumlu bir etki gösterecektir. 2010 y1lında faaliyete geçmiş olan Döngele Kaplıcasını insanlar çeşitli sebeplerle tercih etmektedir. Özellikle de dinlenmek maksadıyla tercih edilen yerler arasındadır. Büyük bir çoğunluğun da kaplıcaya ilk defa geldiği hesaba katılırsa, kaplıcanın gelecek vaat eden bir termal turizm tesisi olduğunu söyleyebiliriz.

Döngele Mahallesinde bugün termal turizm amaciyla iki büyük otel ve apart yer almaktadır. Termal tesislerde çalışan yöneticilerle yapılan mülakatlarda, termal turizm amacıyla gelen ziyaretçiler genellikle Kahramanmaraş, Osmaniye, Şanlıurfa, Hatay, Gaziantep, Adıyaman, Malatya il ve ilçelerinden gelmekte olduğu ifade edilmiştir. Bölge dışından olan insanların burayı pek tercih etmediği 
gözlemlenmiştir. Yöneticiler, termal tesislere olan ulaşımın kısmen yetersiz olduğunu, tesislerin yöredeki istihdama katkı sağladığını, tesislere son zamanlarda turlarla ve sağlık sevki ile gelenlerin bulunduğunu belirtmişlerdir. Ayrıca termal turizm tanıtımlarının yerel boyutta kaldığını, özellikle sosyal medya aracilığ 1 ile (İnstegram, Facebook, Twetter vb.) tüm Türkiye'ye hitap etmesi gerektiğini ifade etmişlerdir.

Genel olarak değerlendirildiğinde, Döngele Kaplıcası bölgenin ekonomik hayatına canlılık getirmiş ve yörede yeni iş yerleri açılmıştır. Turizm faaliyetlerinin de gelişimine bağlı olarak yörede ulaşım imkânları gittikçe iyileşmektedir. Döngele Kaplıcası turizm amaçlı yapılacak olan yatırımlar için bir çekicilik unsurudur. Ayrıca Döngele'deki termal turizm faaliyetleri, yöreden il dışına olan göçü yavaşlatmıştır.

Termal turizme katılanlar kaplıcaya sadece şifalı su için değil, kaplıcada bulunan çeşitli etkinliklere de katılmak ve eğlenmek, bunun yanı sıra gelmiş olduğu yöreyi de gezip görmek istemektedir. Bu nedenle Döngele ve yakın çevresindeki doğal ve kültürel turizm değerlerinin tanıtılması için işletmeler gezi araçları ile turistlere bu hizmeti sunmalıdır. Özellikle, yöre yakınında bulunan Başkonuş tabiat parkına. Sır baraj gölüne, Gene Köprüsüne geziler yapılabilir. Ayrıca tanıtım amaçlı broşürler hazırlanarak tur programları yapılabilir. Yöredeki doğal güzellikler ve yer şekilleri doğa sporlarının geliştirilmesine uygundur. Yörenin ikliminin elverişliliği göz önüne alınarak Türkiye'nin hatta dünyanın ziyaret ettiği bir yer haline getirilebilir. Bunun içinde Uluslararası festivaller düzenlenebilir. Döngele Mahallesinin çevresindeki köylerde üretilen günlük süt, yumurta, peynir, sebze ve meyveler ile diğer kuru gıda ürünlerinin turistlere satış1 için organik tarım ürünleri pazarı kurulabilir. Bu pazar hem turistlerin taze ve doğal ürünlere ulaşmasını sağlayacak hem de çevredeki köylülerin ekonomik kalkınmalarına yardımcı olacaktır. Kılavuzlu Barajından buralara feribot seferleri ve tekne turları yapılabilir. Göl ve baraj kenarı yürüyüş yolları ve bisiklet turları düzenlenebilir. Ayrıca asma köprüler yapılabilir. İnsanlara balık tutma olanăg 1 sağlanabilir.

Türkiye Turizm Stratejisi 2023 Eylem Planı kapsamında oluşturulan GAP Eko-Turizm Odaklı Gelişim Bölgesi içerisinde yer alan Kahramanmaraş, 12 Şubat 2020 yılına kadar birçok turizm alanında destekleme alabilecektir. 2634 sayılı Turizmi Teşvik Kanunu uyarınca Bakanlar Kurulu kararı ile Kahramanmaraş'ta Ilıca Kaplıcası ile Döngele Kaplıcası, Sersem ve Başkonuş Yaylalarını içine alan bölgede Kültür ve Turizm Koruma ve Gelişim Bölgesi ilanı için gerekli inceleme çalışmaları yapılmaktadır. Döngele Kaplıcasının da içinde yer aldığı bu tür projelerin hayata geçirilmesi durumunda yörenin turizm potansiyeli ve yöre halkının bu potansiyelden kazanımları artacaktır. 


\section{KAYNAKÇA}

Alpman, Nazmi (1964). Orta Anadolu ve Akdeniz Bölgeleri Sıcaksu Kaynakları İçmeleri ve Maden Sularının Teknik Envanteri. Ankara: MTA Rapor No:3632.

Babaoğlu, Tacettin (2008). Kahramanmaraş ve Yakın Doğusunun Jeolojisi. K.S.Ü. Fen Bil. Enst., Yayınlanmamış Yüksek Lisans Tezi.

Baydar, Osman ve Yergök, Ahmet F. (1996). Güneydoğu Anadolu - Kenar Kıvrım Kuşağı, Amanos Dağları Kuzeyi ve Doğu Torosların jeolojisi. Ankara: M.T.A. Enst. Derleme Rap. No: 9944.

Çakar, Muzaffer (1996). Kahramanmaraş ve Çevresindeki Şifalı Suların Özelliklerinin Araştırılması. K.S.Ü. Fen Bil. Enst., Yayınlanmamış Yüksek Lisans Tezi.

Çevre Să̆lı̆̆ı (2011). Kaplıca, Kaynak ve Doğal Mineralli Sular. Ankara: MEB.

Edinsel, Sercan ve Adıgüzel, Orhan (2014). “Türkiye'nin Sağlık Turizmi Açısından Son Beş Yıldaki Dünya Ülkeleri İçindeki Konumu ve Gelişmeleri”. Çankırı Karatekin Üniversitesi İktisadi ve İdari Bilimler Fakültesi Dergisi. 4(2), ss.167-190.

Erdoğan, Elmas ve Aklanoğlu, Filiz (2008). "Termal Turizm ve Afyon Gazlıgöl Örneği”. E-Journal of New World Sciences Academy, 3 (1), ss.83-92.

Gül, Murat, Darbaş, Güldemin ve Gürbüz, Kemal (2005). “Alacık Formasyonunun (En Geç Orta Eosen - Erken Miyosen) Kahramanmaraş Havzası İçindeki Tektono-Stratigrafik Konumu”. İstanbul Üniv. Müh. Fak. Yerbilimleri Dergisi. 18 (2), ss.183-197.

İpar, Mehmet Sedat ve Trrıl, Alpay (2014). "Sinop İlinin Kırsal Turizm Potansiyeli ve Geliştirilmesine Yönelik Öneriler”. Türk Bilimsel Derlemeler Dergisi. 7(2), ss.45-54.

Karaoğlan, Hamza (2014). Kahramanmaraş ve Çevresinde Ziyaret Yerleri. Kahramanmaraş Sütçü İmam Üniversitesi Yayınları. Yayın No:148.

Karataş, Muhammet ve Babür, Serap (2013). "Gelişen Dünya'da Turizm Sektörünün Yeri”. KMÜ Sosyal ve Ekonomik Araştırmalar Dergisi. 15 (25), ss.15-24. 
Kırdan, Sait (2004). Döngele, Fatmalı ve Pınarbaşı (Kahramanmaraş) Civarı Tersiyer İstifinin Micropaleontolojik Özellikleri ve Ortamsal Yorumu. Ç.Ü. Fen Bilimleri Enstitüsü: Basılmamış Yüksek Lisans Tezi.

Kop, Alican (2010). "Faylarla İlişkili Jeotermal Alanlarda Radon Gazı Ölçümlerinin Önemine İlişkin Bir Örnek, Hartlap Kaplıcası, Kahramanmaraş”. İstanbul Yerbilimleri Dergisi. 23(1), ss.39-52.

Mergen, Haluk, Erdoğmuş Mergen, Berna ve Erdoğmuş, A. Berkan (2006). "Jeotermal Enerji ve Balneoterapi Uygulamaları". FTR Bilimleri Dergisi. 9(3). ss.108-113.

Ortaç, İshak (2017). Doğu Akdeniz Bölgesinde Bulunan Bazı Doğal ve Kültürel Sit Alanlarının Bitki Örtüsü Üzerine Araştırmalar. Adıyaman Üniversitesi Fen bilimleri Enst., Yayınlanmamış Yüksek Lisans Tezi.

Özkarc1, Mehmet (2007). Türk Kültür Varlıkları Envanteri: Kahramanmaraş. Ankara.

Özkurt, Hatice (2007). "Sağlık Turizmi Tahvilleri”. Maliye Dergisi.152, ss.121-142.

Sandal, Ersin Kaya ve Karademir, Nadire (2015). “Ilıca (Kahramanmaraş) Kaplıcalarında Termal Turizm Odaklı Rekreasyon Faaliyetleri”. Türk Coğrafya Dergisi. 64, ss.39-50.

Sucu, İkbal (1990). "Şifalı Suların Halk Hekimliğinde Yeri ve Önemi”. FABAD Farm. Bilimleri Dergisi. 15, ss.79-87.

Uslu, Ömer Süha ve Kaya, Ali Rahmi (2015). "Kırsal Turizm Alanında Tarım ve Kırsal Kalkınmayı Destekleme Kurumu (TKDK) Destekleri: Kahramanmaraş Örneği”. Uluslararası Sosyal ve Ekonomik Bilimler Dergisi. 5(2), ss.17-24.

Varol, Lutfi, Kop, Alican ve Darbaş, Güldemin (2012). "Koçlar-Sarigüzel (Kahramanmaraş Kuzeyi) Arasında Kalan Bölgenin Jeolojik Özellikleri, Doğu Toroslar”. KSÜ Mühendislik Bilimleri Dergisi. 15(1), ss.43-56.

Varol, Ömer (2003). "Flora of Başkonuş Mountain (Kahramanmaraş)”. Turk J Bot TÜBİTAK. 27, ss.117-139. 
Yereli, Ahmet Burçin ve Kara, Candidate Tuncay (2012). “Türk Devletlerinin Yeni Hamle Sahası: Sağlık Turizmi”. International Conference on Eurasian Economies 2012, ss. 351-358.

Zengingönül, Oğul, Emeç, Hamdi, İyilikçi, Dilek Eser ve Bingöl, Pelin (2012). Sağlık Turizmi: İstanbul'a Yönelik Bir Değerlendirme. İstanbul: İstanbul Kalkınma Ajansı.

\section{İnternet Kaynakları}

https://www.enerjiatlasi.com/hidroelektrik/sir-baraji.html (Erișim: 1202 2019, saat: 13.50).

http://termalrehber.com/kahramanmaras-ili-sifali-sulari-ve-kaplicalari// (Erişim: 20 Kasim 2018, saat: 9.30). 